Western University

Scholarship@Western

Summer 7-3-2019

\title{
Product Categories as Judgment Devices: The Moral Awakening of the Investment Industry
}

Diane-Laure Arjaliès

Ivey Business School

Rodolphe Durand

HEC Paris

Follow this and additional works at: https://ir.lib.uwo.ca/iveypub

Part of the Accounting Commons, Business Administration, Management, and Operations Commons, Business Law, Public Responsibility, and Ethics Commons, Finance and Financial Management Commons, and the Politics and Social Change Commons

Citation of this paper:

Arjaliès, Diane-Laure and Durand, Rodolphe, "Product Categories as Judgment Devices: The Moral Awakening of the Investment Industry" (2019). Business Publications. 32.

https://ir.lib.uwo.ca/iveypub/32 


\title{
Product Categories as Judgment Devices:
}

\section{The Moral Awakening of the Investment Industry}

\author{
Diane-Laure Arjaliès \\ Ivey Business School \\ Western University (Canada) \\ 1255 Western Road, London, ON, Canada, N6G 0N1 \\ darjalies@,ivey.ca \\ Rodolphe Durand \\ HEC Paris (France) \\ 1 Rue de la Libération, 78350 Jouy-en-Josas, France \\ durand@hec.fr
}

Forthcoming at Organization Science.

\begin{abstract}
Product categories are more than classification devices that organize markets; when reflecting market actors' purposes, they are also judgment devices. Taking stock of the literature on product categories and drawing on the distinction between the faculties of knowing and judging, we elaborate a framework that accounts for how and why market actors include or exclude normative attributes in a product category definition. Based on a field study of the development of Socially Responsible Investment (SRI) fund s in France, we describe the phases and conditions of a judgment framework for category definition, for both established and nascent categories. We discuss implications for research on product categories and the workings of markets more broadly.
\end{abstract}

Key words: Categories — Purpose — Norms — Morals — Markets - Investment Industry — Socially Responsible Investment (SRI)

\section{Acknowledgments}

We would like to thank the Editor Ned Smith, and the three anonymous reviewers for their exceptional guidance over the rounds of revision. We also want to thank Sirle Burkland, Sarah Kaplan, Alisson Konrad, Brandon Lee, Martin Messner, Jean-Philippe Vergne and participants in the Ontario Qualitative Methods workshop at the Rotman School (February 2016), the Ivey Sustainability Conference (November 2016), the Aalto, Wharton, MIT/Harvard Research Seminars (April 2017), AOM (August 2017) and the social studies of finance track of EGOS (July 2018) for their valuable insights on earlier versions of this paper. We also want to thank all the practitioners who have never ceased to open their doors, year after year. This research project has benefited from funding provided by the Management Control Association (MCA) and the Society and Organizations Research Center (HEC Paris). It received the Best International Paper in Social Issues in Management and was nominated for the Carolyn Dexter Award (AOM 2017). The opinions are those of the authors and should not be ascribed to others. 
Since Aristotle, social science has distinguished between knowing and judging, and the corresponding faculties synthesized by Kant (1790). Whereas knowing activates the cognitive capacities of agents and audiences in accordance with their individual and collective representations of what is, judging engages a relationship between actors' values and what, in actuality, a category represents and should accomplish with regards to a purpose. Judging implies that actors refer a priori to the values they imbue the category with. Extant research on market categories has produced a vast array of findings about the antecedents and consequences of both categorical membership and violations, relying on the assumption that market actors know, recognize, and make sense of categorical features and cues (Durand and Paolella 2013, Hsu et al. 2009, Hsu and Grodal 2015, Phillips et al. 2013). While past studies focused on market actors' faculty of knowing (categories and their positive attributes), this study explores product categories as a function of market actors' faculty of judging (categories and their normative attributes). This change in perspective raises questions on two accounts. First, while most of extant research characterizes evaluation of categories, few help us understand the normative constitution of product categories, in particular the infusion of normative attributes in existing categories. Second, while many studies document the elaboration and institutionalization of value-laden categories in specific industries (Lounsbury and Rao 2004, Ozcan and Gurses 2017, Weber et al. 2008), there is a need for a general framework accounting for not only inclusion but also silencing normative attributes in product categories.

Taking stock of previous research streams in product category, and social and moral underpinnings of markets, we explore the processes and conditions under which market actors-particularly producerscome to include normative attributes in the definition of a product category. Here, we define normative attributes as characteristics that reveal a purpose or specific values stemming from and referring to the faculty of judging. Normative attributes differ fundamentally from positive attributes (i.e. physical and functional features), as they engage different brain functions, mobilize diverse languages and narratives, and reveal the impossibility of compensatory trade-offs among features. Studying these differences entails analyzing how the faculty of judging is revealed in the definition of a product category, and how changes in attributes represent the expression of normative modifications. Unravelling how producers infuse (or withdraw) a sense of purpose (Hollensbe et al. 2014) into (or from) a product category's definition contributes to elucidate why and how market actors orient the workings and normative content of 
markets more broadly (Durand and Thornton 2018, Fourcade et al. 2013, Fourcade and Healy 2007).

Empirically, we study the definition of the Socially Responsible Investment (SRI) mutual fund product category in the investment industry in France from 1997 to 2017. We use a field inductive analytical approach (Chiles et al. 2004, Davis and Marquis 2005) based on eleven years of participant observation in the industry (2006-2017), 98 semi-structured interviews, and secondary evidence. SRI funds differ from conventional funds by taking into account not only financial criteria but also environmental, social, and governance (ESG) criteria. ESG criteria may include, for example, screening for carbon dioxide $\left(\mathrm{CO}_{2}\right)$ emission levels or human rights violations. In 2015, worldwide investments in SRI funds totaled $€ 12$ trillion, comprising approximately $12 \%$ of all traded assets globally, but representing $25 \%$ of the assets under management (AUM) in France (Novethic 2015). The same year, the French investment industry, in accordance with the French public authorities, was the first in the world to define the SRI category based on the moral purposes of the product, not its technical features (Sapin 2015).

From our analysis of this setting, we derive what we call "a judgment framework of product category definition." We divide this framework into two stable phases ("silencing" and "including normative attributes") separated by an intermediate phase of turmoil ("questioning normative attributes") and four possible paths connecting these phases. This general framework addresses the processes and conditions by which normative attributes are included or excluded from definitions of product categories, for both already established and nascent categories. In explaining how and why market actors come to include normative attributes in their definition of products, we substantiate that product categories constitute more than the cognitive infrastructures of markets—-that is, they involve more than simply the faculty of knowing. Categories also include normative attributes that comprise values and intentionality, although the latter are most often silenced. Product categories hence are not only organizing devices but also function as questioning devices that encourage market actors to reflect on their purposes when producing or buying a specific product. Unravelling the judgmental nature of product categories not only offers novel ways of apprehending those devices for category scholars, it also provides researchers willing to uncover the social and moral foundations of markets with new modes of instantiation and transformation of established practices. Through this contribution, we hope to open new research avenues in how organizations, human beings, and their respective purposes intertwine with the infrastructures of markets 
- a topic increasingly important as normative issues in both markets and societies are becoming of primary concern.

\section{Including Normative Attributes in a Product Category Definition}

\section{Beyond Product Categories as Cognitive Devices}

Researchers have studied the conditions under which the attributes of product categories reduce ambiguity, facilitate identification, and lead to superior outcomes in market exchanges (Granqvist et al. 2013, Hannan et al. 2007, Hsu et al. 2009, Paolella and Durand 2016). To yield ecological advantages (e.g., increased selection by audiences, higher prices, higher valuation, better margins) and to operate smoothly, nothing in a category must hinder an actor's faculty of knowing. Hence, product categories should conform either to prototypes (Hsu et al. 2009) or to audience members' theories of value (Kodeih et al. 2018, Paolella and Durand 2016, Zuckerman 2017). Thus, if product categories are to serve as cognitive interfaces that simplify complex realities, they should not be evolving, complicated, ambiguous, or impure (Hannan et al. 2007, Lounsbury and Rao 2004). For example, when producers span categories, they mix signals and obscure the faculty of knowing what is being offered, thereby complicating the cognitive processes of identification and evaluation (Durand and Boulongne 2017). Audiences tend to sanction producers, conditional on whether there are guarantees of quality (e.g., the high status of the producer), environmental characteristics that make the spanning innocuous (e.g., little contrast between categories), or audiences are able to value diversity and recombine attributes in a more satisfying ensemble (for reviews, see Durand and Paolella 2013, Vergne and Wry 2014). While these findings are coherent and cumulative, they ignore a fundamental aspect of categories in markets: that audiences may consider them as a priori appropriate, moral, or beautiful; i.e., market actors not only know about and recognize categories' attributes but also judge them.

This distinction between knowing and judging echoes Kant (1790), who divided the critique of judgment into the critiques of aesthetic and teleological judgments. In his critique of teleological judgment, Kant discerned our ability to know what is - the faculty of understanding, which associates an a posteriori phenomenon as a specimen of existing universal principles expressed through concepts-from our ability to desire- the faculty of reason, which defines a priori why observable reality should be in a certain way. The faculty of reason is associated with freedom rather than with knowledge. 
By analogy, while prior works emphasized knowledge of and about product categories, we explore the role of categories beside and beyond the faculty of knowing. In markets, certain categories respond to our faculty of judging - i.e., our a priori desire for some ideals, such as doing good by consuming for some or combating the political correctness associated with global warming for others. To clarify and sharpen our point, we rely on Kant's well-known critique and distinction among faculties that has underlied many philosophical discussions about objective versus constructed realities over the past centuries. Hence, we distinguish between the faculty of knowing that consists of assessing a product based on its positive attributes and the faculty of judging that implies projecting ideals onto the product category and assessing it based on normative attributes. A product category actually assembles its definition by incorporating positive attributes recognized by the faculty of knowing ${ }^{1}$ - i.e. physical and functional features easily measurable and commensurable — and attributes that we refer to as normative because they point to purposes and values. Those attributes are per se less measurable, less factual, and less commensurable, thereby activating the audiences' faculty of judging an attribute's goodness or inappropriateness. ${ }^{2}$

Our setting's normative attributes refer mostly to morals: Is there a right (or wrong) way to invest? If so, how do we define a socially responsible investment product? Morals embody humans' highest goals and aspirations, and define what is deemed appropriate (Anteby 2013). However, as formulated by Kant (1790), from whom we borrowed the separation between the faculties of knowing and judging, normative judgments populate a spectrum from aesthetic to teleological judgment. Schematically, these multiple normative judgments can be represented on a normative map with the following two axes: (1) normative constitution toward normative evaluation, and (2) idea/general toward sensation/particular. Regarding

\footnotetext{
${ }^{1}$ Note that positive attributes can be the outcomes of normative discussions (see Khaire and Wadhwani 2010, Lee et al. 2017, Weber et al. 2008).

${ }^{2}$ Attributes referring to social and environmental dimensions (e.g. green products or Fair trade) are often perceived as "normative." It is not necessarily the case in our approach. In our definition, what matters is the type of faculty mobilized by the attribute - the faculty of knowing for positive attributes and the faculty of judging for normative ones. Thus being "energy efficient" does not necessarily imply the faculty of judging, if the agreement upon the quantity of carbon emissions associated with efficiency does not spur any question regarding the goodness or inappropriateness of the qualification. In contrast, due to their unique qualities and the individual experience they involve, ideal and sensational features always require the faculty of judging, and are therefore characterized as normative attributes in our framework. Likewise, we envision all the purposes of a product as normative attributes, even if those appear to be functional or physical. For instance, promising 'value-for-money' i.e. important salary increases after an MBA appears objective, measurable, and is a function of such a program; however, it is clearly not value-neutral as conveying a certain social vision that associates closely human and market values.
} 
the first axis, most of the prior research that studied normative aspects of market categories has dealt with normative evaluation. For instance, assessing the authenticity or a good taste of a product implies that the prototype of the category has already been acknowledged and agreed on—at least temporarily (Goldberg et al. 2016). In the case of Italian wines, producers attribute the label Barolo or Barbaresco depending on the interpretation of wine's mode of production (Negro et al. 2011, p. 1452). By contrast, our investigation concerns the normative constitution of the category. Meanwhile, the second axis extends from sensation/particular to idea/general. A vast majority of prior research on categories dealt with cultural and identitary products (e.g. cuisine, wine, and film). As such, these product categories relate to more particular and corporeal impressions, and hence belong more to the sensation/particular extreme associated with gustative pleasure, beauty, and aesthetics. By contrast, our study focuses on the other extreme, principles and morals (e.g., loyalty and betrayal (Phillips et al. 2013)) which involve higher-level considerations, associated with ideal(ized) characteristics that have universal reach. Our inquiry is therefore situated at the intersection of normative constitution (hence upstream of normative evaluation) and idea/general, but has implications for all types of normative situations, as we will discuss later.

\section{Specificities of Normative Attributes}

When a product category contains normative attributes, the cognitive mechanisms involved in the faculty of knowing prove insufficient. Normative attributes in a category definition place an evaluator in a judgment position rather than a knowledge position. A product offering no longer corresponds with information stored in people's memories (Hannan et al. 2007) or information that needs to be recombined ad hoc when making a purchase decision (Durand and Paolella 2013). Rather, market actors project potential consequences, switching the stance from "is" and "is not" to "could," "should," and "ought to be." For instance, in their study of the early thrift industry in the United States (i.e., mutual selfhelp organizations that first appeared in the 1830s and functioned as saving and loans companies that specialized in real estate loans), Haveman and Rao (1997, pp. 1611-1612) showed that organizers reflected on "what thrift is (not) and what thrift should (not) do" mobilizing "theories of moral sentiment" (Smith 1759) when creating their systems of loans—e.g., "to make good citizens", "to make happy homes, contented communities, a prosperous nation."

In such cases, evidence exists that apparently simple decisions, such as fixing a price, can take a long 
time. For instance, stakeholders inside fair-trade organizations struggled to agree on a "fair" price for producers (Reinecke and Ansari 2015, p. 867). Organizational members ended up having to implement an "ethics as sensemaking" method to reconcile differing views of what constitutes a "fair" price. Similarly, Quattrone (2015) described how the Jesuit Order developed a procedural approach to morals to provide its members with concrete ways to both deal with situations in a case-by-case mode and live their faith as an "unfolding rationality." Due to their inherent difficulties, not evoking normative issues is a common way to overcome the difficulties tied to those attributes. For instance, Anteby (2013) explained how the Harvard Business School developed a shared understanding among faculty of what was deemed good or bad through what he called "vocal silence." Despite the absence of any specific guidance, vocal silence shaped behavior and sustained the morals of the organization over time by embedding them in the routines of the organization by supporting a "deeper metaethical rejection of fixed or objective morals" (Anteby and Anderson 2016, p. 389, see also Ho 2009, Jackall 1988). Those difficulties apply to sensational features as well. Experential goods such as wine (Negro et al. 2011), classical music (Glynn and Lounsbury 2005), fine dining (Rao et al. 2003) or art (DiMaggio 1987) all require individuals to make difficult and personal aesthetic, gustative and emotional judgments that render the workings of such markets particularly complex (Massa et al. 2017, Voronov et al. 2013).

For an organization, the challenges of including normative attributes in the definition of a product category are several. As illustrated by the above studies, normative attributes do not appeal to the same cognitive processes as those sparked by positive attributes. First, normative attributes imply that individuals activate a judgment in an effort to appreciate what the producer's intentionality is and should be. For instance, during the creation of the market for grass-fed meat and dairy products, market actors first had to base their decisions on intuitive emotional reactions- "gut feeling" (Weber et al. 2008, p. 559). Studies in cognitive science concur that the brain areas activated in each decision-making process differ greatly (Greene and Haidt 2002). Individuals who face moral dilemmas activate regions of the brains linked to emotions and affect that are not triggered when processing other information (Greene et al. 2001, Moll and de Oliveira-Souza 2007).

Second, while positive attributes are highly salient and expressed in a language and metrics easily accessible to our faculty of knowing, normative attributes require different narratives and explanations. 
Normative characteristics such as carbon-neutral production, promoting beauty, and transmitting legacy do not benefit from the kind of language and metrics often agreed upon beforehand for positive attributes. For instance, Huault and Rainelli-Weiss (2011) documented how the financial market for weather derivatives failed to develop due to proponents' inability to translate weather risks into positive (financial) terms, as market actors categorized divergently what the market should be. The same difficulties apply to markets of singularities, such as artworks or luxury products, for which judgment devices, such as appellations, critics, guides or rankings, are necessary for consumers to make decisions (Karpik 2010, p. 45-46).

Third, normative attributes slow down the work of identification and evaluation (Murphy 2002). Whereas positive attributes may lead to computational difficulties in terms of combining factors and rank-ordering attributes to maximize one's utility (Barsalou 1991, Durand and Boulongne 2017), they do not entail major problems that substitution rules cannot satisfy. The choice comes down to an arbitrage among preference criteria. However, when normative attributes are added to positive attributes, the utility equation becomes too complex, and for more extreme normative attributes such as morals, no real compensatory trade-off is possible (Boltanski and Thévenot 2006). The cost associated with a normative violation (e.g., lying about authenticity) is not just economic but pertains to a different regime of justification. For instance, beyond its risk/return performance, a "green" investment product that comprises stocks of "brown" companies may deceive and hurt a client's trust for her bank.

\section{Taking Stock of Previous Works and Raising New Questions}

A first stream of research on categories that we referred to previously has centered its attention on the evaluative consequences of category membership when category definitions have stabilized (Hsu et al. 2009, Paolella and Durand 2016). A second stream of research has focused on the processes, practices, and tactics explaining why certain groups come to impose their definition of product categories (Lee et al. 2017, Ozcan and Gurses 2017, Weber et al. 2008). For this stream of research, the emergence and creation of categories stem from rhetorical and power struggles where values and interests confront each other.

As such, Khaire and Wadhwani (2010) described in great detail the formation of the Indian modern art market. They showed that art historians and critics redefined the meanings associated with $20^{\text {th }}-$ 
century Indian art from "provincial" and "decorative" to a "variety of modernism" (p. 1282). Market actors introduced criteria for judging Indian artists and their works based on the evaluative constructs used to assess the work of Western modern artists. By agreeing on the "definitional antecedents of value" (p. 1296), these actors enabled Indian modern art to become a stand-alone category with common evaluation criteria that could be used to price the aesthetic value of such goods.

Weber, Heinze, and DeSoucey (2008) studied the formation of the U.S. market for grass-fed meat and dairy products. The authors showed that social movements mobilized a set of cultural codes, enabling the creation of the market. These codes were constituted by binary oppositions, implying a judgment of what was desirable against what was undesirable: authenticity over manipulation, sustainability over exploitation, and natural over artificial. The movement used such differences to position grass-fed products as alternatives to conventional ones. Grass-fed meat and dairy products were thus not reduced to their calorie and fat content; rather, they evoked a mission involving values of respect for life and earth. The authors explained: "These production stories are self-enhancing for consumers who can associate themselves with these moralities through the act of consumption." (Weber et al. 2008, p. 555)

Likewise, Lee, Hiatt, and Lounsbury (2017) demonstrated how California Certified Organic Farmers (CCOF), the standards organization for California's organic food, used different legitimation strategies to transform the meaning of organic food and thereby support the growth of the market. The CCOF's strategies included the implementation of standardized and rationalized procedures and practices to loosen the original constraints on organic farming, such as authorizing the use of sodium nitrate. These decisions contradicted the personal values and ideals of the pioneering members of the CCOF but enabled the codification of product inputs and the professionalization of the organization.

Thus, some studies pointed to the role of normative attributes in the definition and shaping of product categories. Likewise, scholars interested in social entrepreneurship (Battilana and Dorado 2010, Dacin et al. 2011) and social movement approaches to markets (De Bakker et al. 2013, Durand and Georgallis 2018, Haveman and Rao 1997, Lounsbury 2001) investigated the processes through which individuals imbue market practices with specific values. However, these studies do not offer a general framework for how normative attributes become included or excluded from a category definition but rather specific characterization of particular cases. 
Most research also tends to ignore how the faculty of judging still matters after a category has been established. For instance, once market actors agreed on the criteria for judging Indian modern art, they stopped evoking the meanings associated with the category. Value-laden products such as organic food do not seem to invoke normative attributes in the definition of the product either. In their study of grassfed meat and dairy products, Weber et al. (2008) explained that brokers translated the cultural codes into action frames and language that consumers could understand (e.g., eating authentic, nutritious food), which relegated to secondary importance farmers' moral struggle against conventional agricultural practices. Morality was expressed through stories and imagery— "marketing materials" targeted at "less ideologically committed consumers." (Weber et al. 2008, p. 555-556) Similarly, Lee, Hiatt, and Lounsbury (2017) showed that the shift from producer to product attributes during the standardization of U.S. organic food products led to the disappearance of pioneers' values from the product category. According to existing literature, hence, an agreement on the definition of a product category, necessarily comes at the expense of the maintenance of values and ideals. Therefore, when scholars mention the role of norms and intentions in category product definitions, they typically treat the period of debate over category attributes as a transitional phase on the road to stability and conformity in a market (Durand and Khaire 2017, Hannan et al. 2007, Suarez et al. 2015). As Schneiberg and Berk (2010, p. 258) put it: “once categories are in place, all the politics, debates, struggles to come to terms with novelty, all the work of category revision, experimentation, and redefinition cease, recede from view, becoming buried in the archives, day to day practices, or architectures of markets (Lounsbury and Rao 2004, p. 974).”

However, as illustrated by the 2008 financial crisis (MacKenzie 2011), shifting sentiments about nuclear energy (Garud et al. 2010), and the internationalization of digital services such as Uber and Bitcoin (Vergne and Swain 2017), product category attributes are neither totally static nor totally positive; rather, to different degrees, they can engage our faculty of judging a priori how and what observable reality should be. For instance, while songs and films belong to genres comprising a well-codified categorical system (Hsu 2006), many tunes and films comprise content that appeals to our faculty of judging, not to our faculty of knowing. Likewise, while law practices are well codified, the addition of separate practices can hurt clients' moral feelings and jeopardize trust (Phillips et al. 2013).

Therefore, at their origin, positive attributes may have been shaped by normative conditions and 
arguments about what is "good" versus "evil" or what is "ugly" versus "beautiful." While the definition of a product category could result from oppositions between norms, values, and morals, most papers concede that these debates and fights all recede when products compete on markets: economic comparison relies on positive attributes and commensuration across attributes (Espeland and Stevens 1998, Hannan et al. 2007, Zuckerman 2017). Hence, extant streams of research tend to acknowledge that to be effective, a product category definition needs to evoke attributes that are positive-i.e. well-defined, measurable, observable, and comparable — and study the inclusion and exclusion processes of normative attributes in the definitions of product categories mainly as objects of historical interest.

We aim to complement these research streams about product categories and the moral and social underpinnings of market exchanges with another that acknowledges that, aside from the faculty of knowing what a category is, audiences may desire to confront themselves with categories as they ought to be, thereby invoking a different faculty: the faculty of judging. We elaborate our questioning around the distinction between the faculty of knowing and faculty of judging, and offer a generic framework of the processes and conditions by which product categories come to include or not include normative attributes in their definition, whether in already established or nascent categories.

\section{Methods: A Longitudinal Field Study}

\section{Research Setting}

We study Socially Responsible Investment (SRI) funds, which comprise a significant proportion of the French mutual fund market. A mutual fund is an investment vehicle that pools funds from retail and/or institutional investors and is professionally managed by investment managers to produce capital growth and income. In 2013, the investment industry worldwide was estimated to manage $\$ 100$ trillion in assets under management (AUM), the equivalent of one year of global gross domestic product (Lund et al. 2013, TheCityUK 2014), and was expected to hit $\$ 145$ trillion by 2025 (Benjamin 2017). In 2015, Europe, with $31 \%$ of global AUM, ranked as the second-largest investment market after the United States (at $49 \%$ of global AUM) (International Monetary Fund 2015). France accounted for 19\% of the European market, ranking between the United Kingdom at 35\% and Germany at 10\% (European Fund and Asset Management Association 2015). In 2014, 18\% of conventional funds managed in France systematically integrated environmental, social, and governance (ESG) criteria into their investment processes (known 
as ESG integration), and SRI funds represented an additional 7\% of total AUM (Novethic 2015), mainly among institutional investors (see Figure 1). This means that debates regarding the product category definition of SRI funds directly concerned at least $25 \%$ of French AUM, or approximately $\$ 1.5$ trillion.

\section{Insert Figure 1}

SRI can be qualified as an "extreme setting" (Weber et al. 2008), in the sense that it comprises two elements — finance and morals — usually perceived as opposites (Haveman and Rao 1997, Yan et al. 2018). Unconventional settings can be theoretically ground-breaking since they provide the opportunity to look at phenomena with a new lens, thereby questioning previous understandings (Bamberger and Pratt 2010). Analysis of such settings pushes theories to their boundaries, thereby strengthening their validity. This setting is particularly appropriate for our research goal since it helps us understand how normative attributes (such as morals) can be included in product categories whose features are perceived to be positive (such as in a mutual fund). Note that unlike other national SRI movements, French SRI did not comprise any normative attribute when it was first created, moral concerns appearing only in the aftermath of the 2008 financial crisis, as we will explain below.

\section{Data Sources}

We used an inductive field analytic method that involves tracking changes over time in a particular field (Lounsbury et al. 2003) and follow Davis and Marquis's (2005) problem-driven research approach. Our research is therefore not a retrospective rationalization of a phenomemon as with many cases; instead, we accompanied the unfolding of events, unaware of what the outcome would be. Over an eleven-year period (2006-2017), we collected data from four main sources—interviews, observation, documents and other secondary data.

Interviews. In total, we interviewed 98 informants during 96 group and individual interview sessions throughout the study period: 33 from 2006 to 2009, 36 from 2010 to 2014 and 27 from 2015 to 2017. Interviewees included investment managers; representatives of asset owners (banks, insurance companies, and retirement funds); trade unions; public authorities; brokers; social rating agencies; professional associations; SRI lobbies; non-governmental organizations (NGOs); certification bodies and civil society; and potential users of the SRI label (see Appendix 1 for further details).

Observations. There were two periods of observation. The first one coincided with an ethnography of a 
French asset management company conducted by the first author for her doctoral work, during which she attended approximately 40 formal events per year (2006-2009). This period of observation was intense and was documented in a diary on a daily basis. During the second period of observation (20102017), both authors attended five to six professional meetings per year during which they engaged in informal exchanges with many participants. Finally, in 2015, the first author participated in private meetings between the French professional association of asset management (Association Française de la Gestion Financière, or AFG) and the Ministry for the Economy and Finance, during which the two parties discussed the specifications of the state-backed SRI label.

Documents and secondary data. To complement these data, we performed a content analysis of all SRI-related articles published in French newspapers from 2007 to 2017. We also analyzed all the television reports, radio broadcasts, documentaries, blogs, Twitter accounts, and industry reports we could find on the ongoing debate surrounding the meaning of SRI. Over time, we also secured access to the working versions and the final version of the state-backed SRI label project and the report of the French financial markets regulator (Autorité des marchés financiers, or AMF) on SRI. Finally, we accessed Novethic's database, which includes a systematic analysis of the composition and number of self-identified French SRI funds since 2004.

\section{Analytic Process}

Analyzing the data involved the sequence of sense-making strategies called grounding, organizing, and replicating (Langley 1999), as used by Chiles, Meyer, and Hench (2004).

We adopted grounding strategies to induce new theoretical insights from both field data and theory. First, we used focused coding to identify relevant emerging codes (Charmaz and Belgrave 2002)—that is, terms consistent with the meanings and words of the respondents. As these categories emerged, we began comparing our data-driven conceptual framework with the literature on product categories. In particular, we wondered why it was so difficult for the industry to agree on a common definition and whether something in our study differed from the literature—an approach known as pattern matching (Yin 2013).

We realized at this point that most of the problems discussed by our interviewees related to intentionality and morals. We then refined our data structure around the specific issues faced by the industry and performed axial coding (Strauss and Corbin 1998) by searching for relationships between and 
among these first-order codes and grouping them into second-order codes. For example, actors referred to contradictory goals inside the investment industry with regard to SRI funds (e.g., whether to develop a specific market, or alternatively influence conventional funds). We grouped these codes under the second-order code "moral dimension of the product category." We then collapsed all of our second-order codes into two aggregate constructs, "sources of struggles around the definition of the product category" and "the need to redefine the product category." Using this data structure (see Figure 2), we focused our analysis on the relationships between normative attributes (i.e. morals) and product categories, both theoretically and empirically.

\section{Insert Figure 2}

We used organizing strategies to describe the process data in a systematic fashion (Langley 1999). Using the multiple data sources available, we established a field-level narrative account that chronicled the main critical events influencing the process definition of SRI. When working on the timeline, we observed, over time, variations in the responses to the problems identified in the data structure (i.e., the inclusion of moral attributes in the category). We then used temporal bracketing techniques (Langley 1999) to decompose processes into successive eras separated by discontinuities to determine whether theorized processes were replicated across eras (Chiles et al. 2004). We divided the definition process of the SRI product category into the following three eras (see Figure 3):

(1) Judgment silence (until 2007), the period during which the overall industry actors purposefully avoided discussions on the normative attributes of SRI funds.

(2) Judgment questioning (2008-2012), the period coinciding with the financial crisis sparking criticisms of the moral soundness of the SRI product category.

(3) Judgment inclusion (2013-2017), the period during which a common definition of the SRI product category acknowledged some normative attributes.

\section{Insert Figure 3}

Replicating strategies are techniques for "decomposing the data for the replication of theoretical propositions by phase, by event, and by case" (Langley 1999, p. 707). Once we identified these three eras, we divided the data structure (see Figure 2) into three substructures, one for each era. In doing so, we realized that we could compare the industry's approach on three dimensions: (1) the definition of the 
product category and the presence of normative attributes, (2) the evaluation criteria, and (3) the form of stakeholder engagement. We then reorganized our data analysis according to the three phases and three elements, which led to the structure of the findings presented below.

We triangulated among the sources of data and engaged in cross-temporal analysis, comparing individuals' recollections of past events to the real-time accounts of these events obtained through the different phases of interviews and documentary evidence. We also verified our findings in 2016 and 2018 by sending previous versions of this article to key informants and asking them to provide us with critical feedback. We received only affirmative comments.

\section{The Inclusion of Normative Attributes in the French SRI Product Category}

In this section, we present the three core elements for each phase (judgment silence, judgment questioning, and judgment inclusion), and note whether normative attributes applied. Further details about the various definitions implemented over the years are available in Appendix 2. We position our analyses at the level of the producers (i.e., investment managers).

\section{Phase 1. Stability: Judgment Silence (1997-2007)}

Category Definition: Lenient. Unlike Scandinavian and Anglo-Saxon funds, which were created by "ethical investors," French SRI funds were launched by traditional investment managers (Louche and Lydenberg 2006). The asset management subsidiary of one of the largest French mutual insurance companies created the first national SRI fund in 1997. Although the subsidiary was motivated by social concerns (the parent company belonged to the social economy sector, which put public interest before profits), the SRI fund did not mention any form of morals. By the beginning of the 2000s, a dozen asset management companies had proposed similar SRI funds. The motivations of these investment managers were neither religious (such as in the case of Islamic, Methodist, and Quaker funds) nor societal (such as when Norway's Global Government Pension Fund aimed to preserve national resources for future generations of citizens).

French SRI pioneers hoped to render the financial markets more socially responsible and long-term oriented. To convince other investment managers to also adopt SRI funds, they decided to avoid any reference to moral judgment and instead argued that the integration of non-financial criteria (e.g., the level of carbon emissions) would lead to a more holistic view of a fund, and thereby generate both greater 
investment and better financial performance (Arjaliès 2010, Gond and Boxenbaum 2013). Investment managers willing to raise moral questions were therefore deliberately excluded from industry discussions (Crifo et al. 2018, Giamporcaro and Gond 2016). Through their coercive power, SRI pionners thus imposed their moral silence to the industry (Anteby 2013). As a result, the French professional association of asset management (AFG) defined SRI ambiguously as "integrating non-financial concerns into investment processes." This lenient definition of SRI favored the growth of the market by enabling diverse investment strategies to coexist within an apparently coherent movement (Pontikes 2012).

Evaluation Criteria: Means. To avoid discussing morals that would have sparked difficult questions about which company was socially responsible or not, most French investment managers adopted a "best-in-class approach" that entailed selecting the best socially and financially ranked companies in each sector, regardless of sector content and of firm practices. As long as a mutual fund integrated some nonfinancial criteria, it could name itself SRI. Investment managers judged the best-in-class approachmaintaining broad portfolio diversification — to be the best method for generating financial performance while favoring the most socially responsible issuers. This strategy also enabled investment managers selling SRI funds to avoid normative positions that they perceived to be at odds with the rational and economic anchorage of the industry: "this is not our job to judge, we are here to manage assets, that's it." (informal discussion with investment managers, 2006) The unique and shallow requirement for investment managers was to describe their investment process following the guidelines of the 2005 Transparency Code for public SRI funds created by the French professional association of asset management (AFG) and the French lobby for SRI (Forum pour l'investissement responsable, or FrenchSIF). To be qualified as SRI, investment managers simply had to prove that they integrated nonfinancial criteria in their investment processes-i.e. only the means mattered. Importantly, the code did not address the purpose of SRI funds, which could be and was de facto profit maximization.

Stakeholder Engagement: Weak. Investment managers had few reasons to modify their views and preferences since the industry's representatives never associated any moral attribute with the SRI category. Institutional investors, the bulk of SRI funds' clientele, appreciated the best-in-class approach, which they viewed as a soft way of both integrating non-financial concerns and pleasing trade unions. Few retail clients invested their savings in these products, and as such, were neither vocal nor active via 
consumer watchdog associations. NGOs and the media also did not focus their attention on this product category. The lack of challenge from actors outside investment management leads us to qualify this period of stakeholder engagement as "weak" - both in terms of practical involvement from stakeholders and counter-power. This lack of involvement would not last, however.

\section{Phase 2. Turmoil: Judgment Questioning (2008-2012)}

Stakeholder Engagement: Confrontational. The global financial crisis that erupted in 2008 caused many to question the relationship between financial markets and society. As suggested by Hoffman and Ocasio (2001), some investment managers decided to address the identity challenge raised by the accusation that banks were responsible for the economic and social damages, and seized this opportunity to sell SRI funds to retail customers. In September 2010, the French lobby for SRI funds (FrenchSIF or FIR) organized the first annual national SRI week, and informed the general public about the benefits of SRI through conferences, press releases, and marketing campaigns. The same week, Friends of the Earth, one of the world's leading environmental NGOs, published a press release based on its analysis of the content of porfolios of all SRI funds that were awarded the Novethic SRI label ${ }^{3}$ :

SRI investors remain irresponsible....The financial system remains short-term and the search for a return on investment always higher, at the expense of social and environmental well-being. Without any real guarantee, and because most of the SRI funds are not substantially different from other conventional funds, today this label appears to be totally illegitimate. (Louvel and Rivoalan 2010, p. 17 emphasis in original)

This attack spurred the interest of the media. The NGO was convinced that SRI was a greenwashing attempt from investment managers in the aftermath of the financial crisis. National newspapers across the political spectrum published negative articles about SRI, accusing the industry of deceiving its clients. In 2012, a prime-time national TV show, Cash Investigation, dedicated a documentary to malpractices in the SRI industry, and a scandal erupted. In an epic scene, the star journalist and her camera operator denounced the "false labels." On stage in a landmark professional event, the journalist asked: "How can an SRI fund labeled by Novethic include shares in Transocean, the Swiss firm that was responsible for

\footnotetext{
${ }^{3}$ Novethic, a non-profit organization funded by the French government, launched a label for SRI funds in 2009 that required companies to comply with the AFG-FrenchSIF Transparency Code, disclose their investment approaches, and fully publish their portfolios every six months. This last request was unusual for the industry. Nonetheless, many asset management companies applied for the Novethic SRI label: in 2009, 31 asset management companies representing 121 SRI funds and almost half of the market requested the label; ultimately, 92 funds managed by 25 asset management companies obtained it.
} 
the 2010 Deepwater Horizon oil spill in the Gulf of Mexico?” Investment professionals attempted to explain the "best-in-class approach," and eventually lost ground.

Concurrently, some investment managers started to make their voices heard. Recognized financiers left their banks, and activists echoed their concerns by participating in the public debate through films, books, and TV shows. In 2012, a well-known former SRI analyst, Gaétan Mortier, who was ranked among the top $15 \mathrm{SRI}$ analysts worldwide, wrote articles attacking the professional association's placidity and investment managers' business-as-usual practices. He also published a book entitled Ethical Finance: $A$ Big Misunderstanding, criticizing the approach chosen by the industry. In his multiple press and radio interviews, the author advocated that:

We should not be afraid of "big words" such as "ethics"... It means an SRI movement "with teeth," for which social rating agencies would produce a corpus of independent analysis on all the topics said to be sensitive (tax havens, excessive remuneration of top managers, etc.), with a social prism...rather than a financial prism. (Gaétan Mortier, interview in Libération, 10 September 2012)

Meanwhile, bank employees who sold SRI products found it increasingly difficult to meet the demands of retail clients. As noted in a 2012 informal exchange with an investment manager:

Clients do not understand that we have to select companies among companies that exist. We cannot invent new companies or lend money to their local butcher. They want to invest in a mutual fund and then they are disappointed because it is a mutual fund. What can we do?

Triggered by the public debate, politicians also started to express an upsurge in interest in SRI. A commission responsible for the financial markets created by President Nicolas Sarkozy (2007-2012) thus questioned the industry about the absence of morals in SRI products. In January 2012, presidential candidate François Hollande, favored to win the election in April, declared "war" on his "true enemy:" faceless, unaccountable, and amoral finance (Hollande 2012). For the first time, investment managers had to confront their stakeholders.

Category Definition: Multiple. In the presence of a lenient category definition and mounting contestation, actors saw opportunities to segment and recompose the industry (Durand and Khaire 2017, Hiatt et al. 2009, Pontikes and Barnett 2015). In the aftermath of the scandal, Novethic launched a stricter SRI label that implied some moral commitment. First, counter to the best-in-class approach, Novethic enforced the exclusion of harmful companies (e.g., cluster bomb manufacturers). Second, SRI funds needed to pursue moral goals (i.e., make investments that contribute to a more socially responsible 
economy and society). According to Novethic, the inclusion of non-financial criteria was no longer sufficient to enable a fund to be labeled SRI. To align its deeds with its mission and to break with its past practices, Novethic decided to remove investment managers from the committee that awarded its label.

By breaking the judgment silence tacitly chosen by the industry, Novethic spurred a discussion around the definition of SRI. Some investment managers lauded Novethic's breakthrough: "They are right; it was time to kick the anthill over" (Informal discussions with investment managers, 2013). Other investment managers viewed Novethic as a "betrayer" of the SRI movement, threatening the mainstreaming of SRI, although only Amundi, the largest asset manager in France and Europe, publicly disagreed with this moralizing move toward a definition of SRI that was based on portfolio content. The asset management company officially refused to apply for the new Novethic label and, a few months later, unilaterally initiated a certification project with AFNOR (Association Française de Normalisation, or French Association of Normalization), one of the dominant European certification bodies. The Head of SRI commented:

The evolution of the Novethic label no longer corresponds to our vision of SRI.... SRI is not a regulated market; it is a sort of R\&D for finance. Very selective products, such as our ethical fund Hymnos, must be able to coexist with SRI products with different—and constraining — demands. (Amundi, Head of SRI in Les Echos, 8 October 2012)

The AFNOR certification closely resembled Novethic's prior less stringent label. AFNOR did not include any moral attribute and focused on the processes of investment, rather than on the content of portfolios. Amundi expected that the official status of the leading certifying organization would reassure clients and potentially lead to the formation of an industry standard, which could provide Amundi with a competitive advantage. As a result, fewer funds applied for the new Novethic label (140 in 2012, compared with 182 in 2011), due to a self-selection process: Figure 4 shows that the percentage of rejected applications fell dramatically in the years after the introduction of both new standards, while the total percentage of accredited funds remained stable (between 30 and $40 \%$ ).

\section{Insert Figure 4}

Evaluation Criteria: Means and Purposes. Novethic's and Amundi's attempts to impose their category standards proved unsatisfactory. Instead of providing a clear definition of SRI, they triggered a fragmentation of the product category definition and spurred even more societal criticism. The evaluation 
criteria used to judge whether a fund was SRI diverged. The Transparency Code and the AFNOR certification converged on means: the integration of non-financial criteria into the investment process. Novethic's definition comprised a moral purpose: contributing to a better society. Legally, no obligation existed and any fund could label itself as SRI. To say the least, many clients were confused. Faced with such difficulties, industry representatives decided it was more prudent not to intervene in the debate: "We are not here to judge" (Head of SRI Research, AFG, 2010). Reluctant to regulate the industry, they hoped that competition would solve the issue.

\section{Phase 3. Stability: Judgment Inclusion (2013-2017)}

Stakeholder Engagement: Collaborative. Contrary to the hopes of industry representatives, the controversy did not end. Media interest in the finance industry continued, as did strife among investment managers around what the media called a "raging war of labels." In addition, a new law passed (Article 224 of Grenelle II, 2012), aimed at forcing asset management companies to disclose whether they integrated non-financial criteria. To add to the confusion, the French government officially endorsed the need for only one industry SRI label (Brovelli et al. 2013). The industry representatives had no choice but to reconsider their position to restore a form of industry cohesion: "It is time to distinguish between SRI and conventional funds to maintain a good level of quality among SRI funds...so that they can still play their role of R\&D for the industry" (Responsible for SRI, AFG, 2013).

The professional association launched two working groups: one for investment managers only (including Amundi) and the other for some investment managers (i.e., not Amundi), SRI lobbies, and Novethic. After intense discussions from February to July 2013, both groups agreed to move away from the morally silent SRI definition favored by industry representatives thus far, and to ask the French authorities to endorse this new approach through a label. In their press release, investment managers declared that the SRI label had to "insist on the purpose of SRI and its link to sustainable development" (Association Française de la Gestion Financière and Forum pour l'Investissement Responsable 2013)

In response to the call, the French government created three new working groups: one for investment managers, one for representatives of civil society, and one for certification bodies. The French government aimed to address SRI problems through regulation, in an effort to protect the growth of the investment management industry—a sector judged to be key for France's economic success. At the same 
time, the government aimed to promote France as a leading market place for "green" investments. To achieve both objectives, the consultation process was co-led by the Ministry for the Economy and Finance and the Ministry of Ecology, Sustainable Development, and Energy. Each working group met regularly from July 2014 to June 2015.

While civil society representatives and certification bodies agreed quickly on some principles, investment managers were divided. Each investment manager we interviewed had personal opinions, but only representatives of Amundi and Mirova voiced their concerns publicly. Amundi positioned itself as a global actor committed to "ESG integration" (taking environmental, social, and governance criteria into account in all investment decisions by following the "best in class" approach). It navigated among various national markets and sold both conventional and SRI funds, and hence was highly reluctant to include moral attributes in the French state-backed SRI label. Mirova, created in 2014 as Natixis's SRI brand, held the opposite view: Its SRI funds needed to be as different as possible from conventional SRI funds. Investment managers at Mirova made it clear that they were there to oppose Amundi and push the entire industry toward more socially responsible practices.

In December 2014, despite ongoing disputes among investment managers, the French finance minister, Michel Sapin, declared he wanted an SRI label to be launched: "My goal is clear: to put finance at the service of the sustainable growth of the real economy, and in a way that financial stability and protection to savers are maintained." (Sapin 2014) On September 28, 2015, during the annual national SRI week, Sapin confirmed the creation of a state-backed SRI label. In France, SRI funds would distinguish themselves from conventional funds by their purpose: to contribute to a more responsible economy (Sapin 2015). One year later, the Ministry for the Economy and Finance endorsed the first industry website created to explain the SRI label to the general public, which included the following definition:

SRI is a form of investment that aims to reconcile economic performance with social and environmental impact by financing companies and public organizations that contribute to sustainable development, whatever their activity sector. The SRI label, attributed through a strict labeling process led by independent organizations, is a unique milestone for savers who wish to participate in a more sustainable economy. (Label ISR 2016)

Although tensions remained, these collective attempts to solve the problem led us to describe this period as collaborative from a stakeholder engagement perspective. To encourage the joint efforts, the 
French government would later appoint both Mirova and Amundi as two of the three asset management companies on the committee responsible for managing the SRI label.

Category Definition: Purpose-Based. After so many years of controversial debates, industry representatives came to realize that the definition of a cross-cutting category such as SRI funds brought their existing category schemes and practices into question. The new purpose-based definition contrasted vividly with the previous dominant position of investment managers. Indeed, in their press release, the industry representatives insisted that SRI funds should no longer be judged based only on the means used by asset management companies (the integration of non-financial criteria into investment processes), but rather on the purposes they pursued (the development of a socially responsible economy). As noted by the FrenchSIF president we interviewed in 2013:

We all used to speak about how we constructed SRI funds; we wanted to shift from this approach because we wanted to speak to the general public. Individuals don't care about how the car is working but wonder what it is used for. Then, we thought: We need to define SRI through the goals it pursues.

In doing so, several investment managers explicitly recognized that the first goal of SRI was not financial, thereby addressing criticisms and putting an end to the avoidance of normative attributes. NGOs remained skeptical, but were generally satisfied with this move:

The goal of the campaign is not to shift capitalism, but simply to stop the system from financing the destruction of the planet. We are not opposed to the world of investment in this campaign. We want to put a bit of morality in it, clearly. (NGO C specialized in finance, France Campaigner, 2015)

Evaluation Criteria: Purposes. The state-backed SRI label mentioned the need for SRI funds to both pursue moral purposes and prove that the pursuit of these purposes was effective. "You can pursue whatever goals you want, but this should result in better practices, and you have to prove it" (Informal discussions with investment managers, October 2015). To do so, an SRI fund could choose to: (a) exclude $20 \%$ of companies from the investment universe based on ESG criteria, (b) earn an SRI portfolio grade significantly above that of the investment universe, or (c) implement an impact assessment measure that proved the effect of SRI on investment practices (Ministre des Finances et des Comptes Publics 2016). By transforming the moral intentio (Quattrone 2015) of investment managers into a product category attribute, each asset management company could choose what it judged to be good or bad for society and the economy: there was no normative agreement ex ante. The means also became of secondary 
importance, providing that SRI funds ultimately sought to contribute to a responsible economy. The SRI label was expected to spur questions among consumers about their own morals and the expected overall benefit of SRI for the economy and society.

\section{Judgment Framework of Product Category Definition}

Our historical account traces the development of a product category definition, core practices, and market actors' positions. We now turn to the conditions that facilitated the transitions from one phase to the next and suggest the use of more paths in an attempt to constitute a framework for the inclusion or exclusion of normative attributes in product categories (see Figure 5).

\section{Insert Figure 5}

\section{Transition Conditions in the French SRI Case (Judgment Inclusion)}

We found two conditions that fostered the transition from judgment silence, a phase of stability, to judgment questioning, a phase of turmoil in which product attributes are challenged.

Transparency of Means. Investment managers initially attributed the criticisms faced by the industry to a lack of understanding by external observers who had little financial expertise (hence a poor activation of the faculty of knowing). They hoped that by better explaining the workings of SRI, they would be able to educate people and make apparent the merits of the best-in-class approach. As such, they defended the AFG-FrenchSIF Transparency Code and remained opposed to the idea of an industry SRI label: “Financial professionals don't want [a label]. The simplest way to [standardize behavior] is to adopt the Transparency Code” (Bank C, CSR Deputy Director 2010). Novethic endorsed this transparency approach in 2009, when creating its first label whose main feature consisted of publishing the content of all the portfolios that had been awarded the Novethic label.

The transparency of means led to the questioning phase in two ways. First, it provided stakeholders with access to the practices of investment managers. Because Novethic made all the portfolios available, Friends of the Earth was able to write its critical report about SRI—a report it had wanted to write for years but could not for lack of evidence. Likewise, it was the transparency of Amundi and Novethic that enabled the TV journalist to interview their representatives unprepared, which gave rise to further criticism. 
Second, the growing transparency of means increased the divide between the industry and its critics. For years, investment managers resented the media and NGOs' dispute about the benefits of the best-inclass approach; some described themselves as victims of the "witch hunt" that followed the financial crisis. By being open about their decision processes, investment managers provided an answer that appealed to the faculty of knowing to what they perceived to be an ignorance problem about concrete situations and procedures. The media and NGOs, in contrast, associated the term "socially responsible" with normative judgments about what was good and bad, not with the adequacy of a technique or a process. Stakeholders wanted to hear about the "real motivations" of financial actors, not about the practical details of the investment selection. Investment managers were instead elaborating on the functional features of the product, in accordance with what the industry described as a "rational" and "objective" investment practice, ${ }^{4}$ while critics placed morals and societal questions at the center of their evaluation. Consequently, the more process-oriented, technical, and transparent the answers of investment managers were, the more their detractors believed that investment managers refused to disclose their "true" (financial) motives.

Public and Private Contestation. The ability to publicly and privately contest the lenient definition of SRI was also key to entering the phase of turmoil. During the phase of moral silence, several investment managers attempted to criticize the dominant industry practices but were not sufficiently powerful, organized, or numerous—and were therefore reduced to silence.

The financial crisis catalyzed the attention of many actors (Hoffman and Ocasio 2001), enhanced public scrutiny, and led to public and private contestation. As demonstrated in the context of scandals, the conjunction of critical events and publicity whip up criticisms that diffuse broadly (Adut 2005). In the case of French SRI, journalists, NGOs, and activists brought contestation to the public sphere via the press and social media. The industry representatives we met with in 2010 confessed that, as shown by the TV episode of Cash Investigation, they did not know how to handle the (social) media. These interactions were quite different from the discreet forms of self-regulation they were used to. It was this media game

\footnotetext{
${ }^{4}$ Note that such qualifications actually convey a specific societal vision of what the purpose of the industry should be: profit maximizing through the use of calculative devices anchored in economic and financial mathematics (see Arjaliès et al. 2017, Knorr-Cetina and Preda 2012, Ortiz 2014).
} 
that nevertheless attracted, in turn, the attention of the French government and ushered in the phase of turmoil.

One of the big issues that industry representatives faced during this period of turmoil was that no regulation was in place to manage disputes between investment managers. When faced with similar problems (e.g., regulation), investment managers usually shared a common goal (i.e., market growth), reached agreement behind closed doors, and then communicated the industry position through a press release or informal exchanges. Professional meetings on SRI, in contrast, were conflictual and tense. In cases of disagreement, the professional associations (AFG and FrenchSIF) had no power to enforce any decision on their investment manager members. After these episodes of contestation, both the professional association (AFG) and the French lobby for SRI (FrenchSIF) changed their governance processes and clarified the goals they were pursuing through SRI, notably through a charter that all members had to sign (FrenchSIF).

By raising their concerns publicly, the media, NGOs, and activists also offered dissident investment managers an opportunity to voice their concerns. Investment managers were no longer afraid of questioning the moral silence of the industry —-they could use the public contestation to justify their apprehensions. For instance, some investment managers used Twitter accounts and journalists to advance their causes—even leaking information to the press during the state-backed SRI labeling process in an effort to influence the negotiations. Conversations with these investment managers indicated that they perceived themselves as social activists—and as such they felt closer to some NGOs than to some other investment managers. This internal contestation meant that moral silence could no longer be maintained. The professional convention—of maintaining a united front when under attack—cracked, as more finance professionals themselves experienced the tension between their faculties of knowing and judging.

Therefore, the transparency of means and public and private contestation are the transition conditions that led to the "judgment questioning" phase. At this point in the process, the inclusion of moral attributes in the SRI product definition was facilitated by two distinct conditions: identity introspection and threat to market.

Identity Introspection. Identity introspection corresponds to how individuals experience the moral tensions revealed by the disconnects between practices, discourses, and product contents. As attacks and 
criticisms against core practices and organizations intensify, organizational members as individuals accept or oppose blind compliance with organizational rules and principles (Lok 2010) but are constrained by their organization's policy. During internal discussions to define SRI, some individuals found themselves representing multiple identities, blurring the message, and confusing the audience:

The true problem is that we never know in whose name anybody speaks. Is it a personal position, the industry's, the company's?... We have a true problem of governance; we are facing a true crisis of governance. How should we decide? (Asset Management Company P, CEO 2015)

At an individual level, an investment manager might support a vision of SRI, but her bank might oppose the definition adopted and the associated rigidity. This situation could lead to identity tensions in which the product category causes top executives and investment managers to question the meaning of their occupation, their influence, and freedom (as in Creed et al. 2010). "We are investment managers; we are here to manage assets but we are also individuals, parents, consumers, etc. We are all of that and this is not that easy to deal with" (Asset Management Company N, Head of SRI, 2015). On the ground, financial advisers also found it difficult to understand (and therefore sell) these products. Many could not answer simple questions. For example:

Last time, a client asked me about this fund. We started looking at the portfolio together, and we discovered that Total was in it, the French oil major! He told me that this company was not socially responsible. I agreed with him. What else could I have told him? (Financial Adviser, Bank F, 2015)

Thus, financial advisers mostly offered conventional funds to retail clients in an attempt to avoid uncomfortable questions. Likewise, investment managers found it particularly difficult to sell both conventional and SRI funds. They particularly worried about the cohesiveness of their discourses across products. On the one hand, greenwashing accusations could threaten asset management companies' reputations; on the other hand, questions about conventional funds' societal impacts could provoke further criticism of these products. These difficulties in selling both conventional and SRI funds led some investment managers to question the moral grounds of the industry itself. They wondered what the purpose of their profession was after all:

Are we here to fabricate socially responsible products that will generate better financial performance in the long term, assuming our responsibility in the markets and driving change towards a sustainable and fair economy? Or are we just here to do what the clients want, even if this means harming the planet by continuing to invest in a short-term and narrow manner? (Asset Management Company P, CEO, 2015)

Threat to Market. This identity introspection led a handful of investment managers to realize that if they 
kept fighting with one another, SRI would certainly vanish. The proponents of ESG integration (incarnated by Amundi) and those who opposed this best-in-class approach (incarnated by Mirova) were two sides of the same coin—neither could flourish if SRI was being accused of greenwashing. Competition needed to occur downstream (after reaching agreement on an SRI definition), not during the category definition process. Industry representatives and the government also worried about the potential damage these confusing messages could inflict on the development of the entire industry by weakening the credibility of investment professionals. Some NGOs and lobbies eventually acknowledged that SRI was instrumental to the transformation of the financial markets they pursued and should therefore be protected. Gradually, everybody involved in the discussion started asking the professional associations to address the problem. Independently and in coordination with the French government, the industry representatives then opened a multi-party discussion and reconciled in a single definition the contentious positions taken by different funds, as reflected in Amundi and Mirova's emblematic positions.

During this process, investment managers reached out to politicians to obtain their support, not for market deregulation as it was usually the case, but instead to push for a stringent SRI label.

We came and explained to them: You have to increase the regulation on SRI, not weaken it. They [Ministry for the Economy and Finance] did not understand it, at all. Usually, we do the contrary. (Informal discussions with three investment managers, 2016)

Investment managers who perceived themselves as social activists hoped to advance their societal agenda. Investment managers who had no particular societal purpose saw a market opportunity in this moralization of the industry. In the aftermath of the December 2015 Paris climate conference (at which 195 countries adopted the first-ever universal, although non-binding global climate deal), the French investment industry could make the most of this SRI label to demonstrate its capacity to deal with any type of normative issue (e.g. SRI, green or Islamic finance). For governmental authorities, SRI represented an opportunity to position the country as the world leader in the fight against climate change and to forge a new relationship between finance and society - a connection that had been broken in the past decade. In the years following the financial crisis, SRI stood both for the errors of the past and for a new, better future for the industry.

\section{Framework Extension}

Figure 5 offers a judgment framework of the product category definition, or how normative attributes are 
made visible in a product category definition. In the French SRI fund case, the process began and ended with phases of stability, with a phase of turmoil in between; specific conditions facilitated transitions between the phases (represented by the solid, downward-facing arrows in Figure 5). Judgment inclusion is only one of four possible paths. Our model illustrates three other possible trajectories: Judgment Silencing, Reversion to Silence, and Judgment Maintenance (see Figure 6). In this section, we elaborate on three other product categories belonging to the finance industry that present similar characteristics with SRI, yet experienced a different path: Islamic finance, collateralized debt obligations (CDOs), and life insurance. These cases show how amenable our judgement framework is to extensions that help acknowledge different paths of inclusion (or not) of normative attributes in product categories (see Figure 6). Transitions conditions are the same leading to the Questioning phase and have been adjusted to lead to the Silencing phase (vs. to the Inclusion phase): market opportunity (instead of threat to market) and identity muting (instead of identity introspection). Note that these model extensions are more speculative than the analysis developed around our focal case (SRI); as such, they require further investigation and empirical testing, for which we hope our framework could provide a first theoretical basis.

\section{Insert Figure 6}

Judgment Silencing. The second path of our model is Judgment Silencing, where a purpose-based product category, such as Islamic finance, gradually loses its normative anchorage. Islamic finance is often defined as an "interest-free" financial product that needs to obtain a balal certification by accredited Sharia scholars to prove the compliance of the mutual fund with the Sharia law (Hayat et al. 2013). Islamic finance is a complex setting whose intricacies and nuances cannot be faithfully accounted for within the space of this section. Islam counts more than 1.5 billion followers on the globe, associated with many different interpretations of the Sharia law. The trajectory of Islamic finance, however, broadly associates with a movement from judgment inclusion toward judgment silence.

The modern form of Islamic finance arose in 1974, when 44 countries founded the Islamic Development Bank (IDB). Islamic funds shared a common purpose: to build a financial system that respected Islam precepts and preserved the destiny of Islamic countries. Islamic finance was a collaborative purpose-based product category whose definition was grounded in the inclusion of normative attributes based on the Sharia (i.e., the phase of Judgment Inclusion). Soon afterwards, Islamic 
financiers-governments and private-sector pioneers_created the International Association of Islamic Bank (1977) and published the Handbook of Islamic Banking, which became the reference for Islamic institutions. In the following years, initiatives proliferated with a special focus on building the academic knowledge of Islamic finance and extending Islamic finance to the general public (Warde 2000, p. 77).

However, the transparency of investment practices and the efforts to convince investors of the soundness of the approach spurred critics. Furthermore, the more individuals looked at the investment processes, the more questions were raised. As a result, some countries started launching their own Islamic banking systems with their own rules and systems of certification (Warde 2000, p. 83). By the 1980s and 1990s, the transparency of means and public and private contestation had led to an intense phase of judgment questioning in the industry, which was regularly nurtured by scandals, such as the collapse of the Bank of Credit and Commerce International (BCCI) in 1991. Evaluation criteria varied (including means and purposes), definitions diverged, and conflicts endured (i.e., the phase of Judgment Questioning).

Critics are still alive in the Islamic bank sector (see Pitluck (2012) for some discussion of the problems at stake). Yet, many countries have shifted toward a phase of stability around "judgment silence." Islamic finance is gradually loosing its religious rhetoric (Ernst \& Young 2011), which is notably the case since many Islamic finance products are now sold outside the Islamic world, through partnerships between conventional and Islamic institutions. The two transition conditions "market opportunity" and "identity muting" progressively lead to the silencing of the normative attributes of the product. Majed Al-Refai, chief executive of the Bahrain-based First Islamic Investment Bank, explained: "Our aim is to create credit-rated medium- to long-term investment tools which are comparable with existing conventional products, so that financial advisors can advise their clients to invest with us on the basis of returns, rather than because they are Islamic" (cited by Warde 2000, p. 86). In the aftermath of the financial crisis, Islamic finance has been praised, not for its religious ethics, but for its ability to mitigate risk exposure (Hasan and Dridi 2011). For an increasing number of observers, Islamic finance has become a diversification opportunity that everyone interested in making money should embrace (Arouri et al. 2013). The silencing of its normative attributes hence progressively diffuses, leaving investors with a lenient product category, whose evaluation is based on means, and whose growth gives market actors little 
interest to voice their concerns (i.e., the phase of Judgment Silence).

Reversion to Silence. The second path of our model is "Reversion to Silence," during which a phase of judgment silence is followed by a phase of judgment questioning, yet the product category reverts to judgment silence. Such a process unfolded in the case of collateralized debt obligations (CDOs), which are financial products that pool cash-flow-generating assets and repackage those assets into tranches. The pooled assets (i.e., mortgages, bonds, and loans) serve as collateral for the CDOs.

CDOs attracted much criticism in the aftermath of the financial crisis. The International Monetary Fund estimated in 2008 that half of the $\$ 1.4$ trillion losses came from structured financial products such as CDOs (International Monetary Fund 2008). The financial crisis made these investment practices known and visible (i.e., the first transition condition) and spurred a tide of public and private contestation (i.e., the second transition condition). Research detailing the mechanisms through which critics arose from within and outside the investment industry regarding the lack of morals associated with such investment practices (see Davis 2010, MacKenzie 2011, Pozner et al. 2010 for some reviews). The product category became an iconic incarnation of the greediness of finance and led to an intense phase of judgment questioning.

What few individuals know, however, is that CDOs are still being used today. It is estimated that the sales of synthetic CDOs rose from $\$ 20$ billion in 2015 to $\$ 100$ billion in 2017 (Citigroup 2017). Recently, in a double page titled, "This Time It's Different—Back to the Future," Thomson Reuters explained that banks are "decontaminating the once-ignominious synthetic CDO" (International Financing Review 2018, p. 100). The process of reversion to silence could probably not be clearer. The motivations of investors are said to be mainly financial. CDOs present high-yield opportunities, and credit derivatives desks are eager to make profits. The first transition condition "market opportunity" hence certainly explains most of this reversion, but the second condition "identity muting" also plays a role. MacKenzie and Spears (2014) showed that designers of CDOs actually questioned to a large extent the models they created, often considered them as flawed. Yet, modelers kept using the same models, even when alternatives were available. The main argument put forward by the authors to explain such a paradox is the complexity to coordinate within the market. The model (i.e., the Gaussian Copula) is actually used by modelers not because it is statistically accurate, but because it offers market actors with no shared culture 
a common basis for pricing CDOs. The model is a necessary evil to maintain the market. In other words, CDO-market actors swept under the carpet their potential discomfort and any questioning about their instruments and their connection with reality. They stifled their identity differences and maintained the product in its original form (i.e., our first transition condition "identity muting"). Hence, both conditions account for the reversion to moral silence of the product category.

Judgment Maintenance. The last path of our framework extension is "Judgment Maintenance" where a purpose-based product category based on normative attributes is questioned, but maintains its normative basis. A good example of such a process is the development of life insurance in the $19^{\text {th }}$ century in the United States (Zelizer 1978). Life insurance first appeared as an answer to the increasing economic destitution of widows and orphans of low-paid Presbyterian and Episcopalian ministers. The goal was explicitly altruistic and spurred by religious beliefs. Life insurance thus emerged as a purpose-based product category, based on normative attributes.

As in the previous cases, the product category soon attracted critics. In particular, the clergy was divided. One group denounced a "sacrilegious device that competed against God in caring for the welfare of widows and orphans" (Zelizer 1978, p. 596). The other group, which included religious liberals, supported the industry, notably for its practical (i.e., financial) considerations. Some reluctance also emerged among the general public who tended to reject any monetary evaluation of human life and worried that such contracts would provoke their death. The transparency of the (financial) means together with the public and private contestation led to a phase of questioning, which hindered the development of the market during the first part of the $19^{\text {th }}$ century.

Many cultural factors explain why life insurance gradually became legitimate during the second half of the $19^{\text {th }}$ century, and notably relate to functional changes in the family, due to urbanization. Of interest for our framework is that the legitimacy of the life insurance product did not unfold through the silencing of its moral attributes, but rather through their explicit inclusion in the product category itself. Until the late $19^{\text {th }}$ century, the life insurance industry indeed avoided any economic terminology and advertised mainly its moral value, rather than its monetary benefits (Zelizer 1978, p. 600). Even when discussions around the economic value of life started to appear in the industry in the $20^{\text {th }}$ century, market actors were quick to transform life insurance into a "secular ritual" (Zelizer 1978, p. 602), not a commodity. Clients 
needed to be reassured that "marketing death served the lofty social purpose of combatting poverty, thereby reducing crime" (Zelizer 1978, p. 605-606). Without including moral purposes in the definition of the product category, the market hence could have not developed (i.e., the first transition condition of Threat to Market).

The second condition, Identity Introspection, also played a role. It was only after insurance companies introduced personal contact between agents and beneficiaries that sales started to increase. Unlike other products, life insurance required individuals to reflect on and share their views about death and its meaning. This identity introspection was facilitated by the work of agents who were urged to "remain above materialistic concerns, performing their task with the spiritual devotion of a missionary" (Zelizer 1978, p. 607). Through such exchanges, producers and clients maintained the normative basis of the product category.

The trajectories of SRI, Islamic finance, CDOs, and life insurance show that, depending on conditions, normative attributes are likely to be silenced, questioned, or included. The fact that the four products belong to the same industry as SRI provides additional evidence that the transition conditions matter more to the trajectory than industry-specific characteristics.

All four products belong to the "idea/general" side of the normative map of product categories rather than the "sensation/particular" side we described earlier, which is more applicable to experiential and cultural products such as food and other hedonistic products. Discussions around SRI and life insurance mostly concerned the normative constitution of the category, whereas the conversations that surrounded Islamic finance and CDOs related more to normative evaluation, since these products were questioned after a (tacit) agreement on their normative features was first obtained.

Our model would be enriched by further investigation of other settings, in particular along the sensation/particular axis. To encourage such research, we list below some products that have raised normative questions when constituted or evaluated, and could be potentially studied through the lens of our judgment framework. On the normative constitution, tablets and other experiencial products (e.g. virtual reality) might be good products to examine. Indeed, when the iPad was first launched, audiences did not understand what a tablet was in practice and were therefore unable to categorize the product (Watkiss 2013). Artificial intelligence (AI) also raises questioning in its multiple usages (e.g., human 
replacement, intimate functions from conversation, post-death AI mourning, or even sexuality) (Russell and Norvig 2016). On the normative evaluation side of the map, products such as agri-tourism (Tew and Barbieri 2012) have sparked debates about the positive versus normative aspects of marketizing culture and nature. The same perspective applies to inductive teaching for which conventional evaluation has been said to be limited in its ability to account for the uniqueness of the method (Zhai et al. 2017). We hope our model (Figures 5 and 6) can offer some analytical guidance for further research.

\section{Implications and Discussion}

In this research, we investigated how and why producers (i.e., investment managers) agreed to include normative attributes in the definition of a financial product category: French SRI funds. After a phase of judgment silence about the normative attributes of this product category, investment managers entered a phase of judgment questioning before market actors reached an agreement to include a moral purpose in the product definition. We identified transition conditions and elucidated three additional paths in addition to judgment inclusion that together constitute the judgment framework depicted in Figures 5 and 6. This article thus answers recent calls for research to provide a better understanding of the debatable nature of the definition of product categories (Durand and Thornton 2018, Granqvist and Ritvala 2015), which are not merely cognitive and strategic representations but also judgment-based classifications. We believe these findings have important implications for the literature on product categories and the moral and social underpinnings of markets more broadly.

\section{Product Categories as Judgment Devices}

Market actors tend to silence their moral dispositions and beliefs as economies are thought to be valueneutral, objective profit-maximization structures (Fourcade et al. 2013). Our judgment framework (Figure 5) exhibits the paths that lead product categories both to include (or not) more than positive attributes (physical properties and functionalities) and to encompass normative attributes that point to values and purposes. Product categories are classification devices that organize markets, certainly; but they are also judgment devices conveying particular norms and ideals. As such, the attributes of some established categories can be questioned, as transparency around their practices reveals behaviors and attitudes that become morally tainted and a subject of public and private contestation. Hence, judging categories' attributes occurs when categories form and also when they have been in existence for long. 
Furthermore, drawing on a long-established distinction between faculties (first synthetized by Kant's (1790) critiques and refined since then), we make central the faculty of judging in market exchanges. Most commonly, product category research refers to the faculty of knowing, whereby positive attributes lead to comparison and similarity-based evaluation to identify and assess candidates (Hsu et al. 2009). Another vein of research explains that audiences recombine attributes and evaluate candidates as a function of how well this recombination matches their goals and needs (Paolella and Durand 2016). In both instances, however, the conception of judging is limited to the identification of positive attributes as acceptable, coherent, and beneficial. By invoking the faculty of judging, we introduce a difference in nature.

As developed by Kant (1790) and many other social scientists, normative attributes involve a purpose that, based on specific values, audience members assess a priori as moral (good/bad) or aesthetic (beautiful/ugly). Normative attributes differ fundamentally from positive attributes, as they engage different brain functions, mobilize different languages and narratives, and reveal the impossibility of compensatory trade-offs among features. As the examples developed in the article illustrate, individuals within and outside organizations struggle to reconcile objective characteristics of the products they have to sell or they want to buy with their emotional appeal for "doing good". The faculty of knowing and the faculty of judging do not function in an "either-or" mode. A similar feature can be subject to both faculties, which explains why, for some individuals, internal tensions and identity introspection are generated when the faculty of judging supersedes the faculty of knowing. Such a situation was evidently the case for financial advisers facing the moral imperative of selling "products good for the planet" (i.e., SRI funds), which were actually similar to any other fund. While risk/return narrative is operative in many finance segments, the narrative around SRI is subtler and reveals inner contradictions and insuperable tradeoffs in the features and goals of SRI and of any other financial product. The product category literature has been ignoring the gradual questioning of many products and markets, on the grounds of their morality. Likewise, scholars interested in the social foundations of markets have not fully investigated the role of product categories in the normative constitution and evaluation of markets. We contribute to these literatures by describing and theorizing how a product category's definition instantiates actors' purposes and values, and how changes in attributes represent the expression of 
changes in the motivation of actions. We deduce four paths leading to normative attributes' inclusion or exclusion in the definition of product categories (i.e., judgment inclusion, judgment silencing, reversion to silence, and judgment maintenance; see Figure 6).

The transition conditions revealed by our analysis differ from the conditions that explain why positive attributes are included (or not) in a category definition. For instance, when positive attributes are disputed, there is often a need for transparency only among a few professionals and experts, little presence of public contestation, and far less identity introspection or muting. By analyzing one specific case of judgment inclusion, our framework helps further our understanding of the mechanisms through which market actors agree on the "definitional antecedents of value" (Khaire and Wadhwani 2010, p. 1296). Hence, product categories, which have long been considered as the cognitive infrastructures of markets, also constitute the normative underpinnings of markets. Our three-phase framework makes explicit its constituents and the transition conditions between them.

\section{The Workings of Purpose-Based Product Categories}

Setting a purpose for actors to follow in a product definition constitutes a solution to the absence of compensatory trade-offs among the multiple dimensions of the product. Whereas it is possible to arbitrage between positive attributes, normative attributes raise distinct challenges that can find resolution by defining the category from what it aims to achieve. In our case, social responsibility implies an indefinite set of features and situations, which prevents market actors from listing them all. When a normative attribute characterizes a product category, its definition cannot rely on a classic form of commensuration (Espeland and Stevens 1998). Evaluation schemes of normative attributes imply projection, reflection, and self-questioning rather than the identification of traits, similarity reasoning, and conceptual combination, which comprise the basis for traditionally evaluating product categories (Durand and Boulongne 2017). Envisaging categories as judgment devices encourages producers and audiences to become conscious of their own purposes and values with respect to products (as in Quattrone 2015, Reinecke and Ansari 2015). Note also that a purpose-based category contaminates other product categories by making them appear less valuable and less meaningful to some audiences. While most product categories strive to simplify the purchasing act, purpose-based product categories render the purchasing act more complex by acting as questioning devices for producers, third parties, and clients. As 
such, our framework furthers our understanding of why market actors compromise (or not) the competitive benefits and cognitive efficiency of crisp category definitions carried out by positive attributes - since the inclusion (or withdrawal) of normative attributes displaces the traditional processes of identification and evaluation detailed in prior research.

Last, unlike previous research, we propose that defining a product category with normative attributes enables the maintenance of values in the product category, contrary to what happened in the organic, recycling, and grass-fed meat and dairy movements (Lee et al. 2017, Lounsbury et al. 2003, Weber et al. 2008). In a purpose-based category, the judgment process is actually essential to the categorization of the product and the workings of the market (Durand and Thornton, 2018). In the case of SRI, only the intention incorporated into the product (contributing to a sustainable real economy) distinguishes the mutual fund from a conventional one. Our article hence suggests that market actors can define and enact product categories to pursue alternative purposes or other "fictional expectations" (Beckert 2016), such as solidarity, well-being, or diversity (Hollensbe et al. 2014, Marti and Scherer 2016).

\section{Judgment Framework of Product Categories: Boundary Conditions and Limitations}

Before concluding, it is worth mentioning several boundary conditions of this research. First, our study explores normative attributes in the form of morals, and extension to other normative attributes may require adjustments. As such, our model can be applied to normative attributes that evoke particular sensations, such as taste, pleasure, and aesthetics, for which the faculty of judging would estimate, for instance, loyalty to the original, respect of processes, introduction of creative surprises, and genuineness of intention. However, since we use this case to elaborate a framework rather than to test specific hypotheses, its extension will weigh more heavily on future empirical tests.

Second, the economic crisis of 2008 seems to have fueled the questioning phase. In our framework, is a crisis or an environmental jolt necessary to upend a stable phase (i.e., silencing or inclusion)? We doubt it. The framework extension indeed shows that jolts are not always present. However, some actors need to convey new information about the sector, the producers, and the categories. Hence, a boundary condition consists in the possibility for this information to flow and reach audiences of interest. Likewise, public contestation between producers and other parties, similar to private contestation within firms and producer associations, needs to be possible, thereby implying a regime of sufficient free speech or at least 
institutional conditions that are safe enough to allow for the sharing and discussion of discrepant views.

Third, because this research represents a single case study, its generalizability is questionable. There is indeed an inherent historical embeddedness of categorical meanings (Khaire and Wadhwani 2010, p. 1297). The national context also presents some specificities, notably the visible hand of the French state- a role of the political sphere pointed to by previous research on the definition of product categories but so far little studied (a recent exception is Ozcan and Gurses (2017)). In other countries or industries, other actors may have played the same coordination role. Much work remains to be done to refine the conditions explaining why some product category definitions will move toward (or away from) normative attributes, but our model provides the essential building blocks and transition conditions around which more refined elaborations can unfold. Such findings offer the potential to rethink product categories not as stabilized devices with a steady meaning and functions but as an inherently dynamic and contested process that appeals as much to market actors' faculty of judging as to their faculty of knowing. Avenues for further research concern the role of multiple actors in such processes, linking the judgment framework with the literatures on morals, institutional theory, or the sociology of valuation.

\section{Conclusion}

Increased questioning of market functioning, including its underpinnings and purposes, is transforming the roles and responsibilities of producers, and the functions of product categories. When faced with these changes, scholars need to find new ways of understanding the normative component of markets and its impact on consumption and society. We believe that this endeavor must be accompanied by changes in how we perceive and theorize product categories. Presenting a judgment framework of product category definition is a step in this direction, one we hope more researchers and practitioners will follow. 


\section{REFERENCES}

Adut A (2005) A theory of scandal: Victorians, homosexuality, and the fall of Oscar Wilde. Am. J. Sociol. 111(1):213-248.

Anteby M (2013) Manufacturing Morals: The V alues of Silence in Business School Education (University of Chicago Press, Chicago).

Anteby M, Anderson C (2016) Management and Morality/Ethics: The Elusive Corporate Morals. Wilkinson A, Armstrong SJ, Lounsbury M, eds. Oxf. Handb. Manag. (Oxford University Press, Oxford, UK), 386-398.

Arjaliès DL (2010) A social movement perspective on finance: How socially responsible investment mattered. J. Bus. Ethics 92:57-78.

Arjaliès DL, Grant P, Hardie I, MacKenzie D, Svetlova E (2017) Chains of Finance: How Investment Management is Shaped (Oxford University Press).

Arouri M, Ben Ameur H, Jawadi N, Jawadi F, Louhichi W (2013) Are Islamic finance innovations enough for investors to escape from a financial downturn? Further evidence from portfolio simulations. Appl. Econ. 45(24):3412-3420.

Association Française de la Gestion Financière, Forum pour l'Investissement Responsable (2013) Communiqué de presse: L'ISR adopte une nouvelle définition afin de mieux se faire connaître des épargnants (Association Française de la Gestion Financière \& Forum pour l'Investissement Responsable).

Bamberger PA, Pratt MG (2010) Moving forward by looking back: Reclaiming unconventional research contexts and samples in organizational scholarship. Acad. Manage. J. 53(4):665671.

Barsalou LW (1991) Deriving categories to achieve goals. Bower GH, ed. Psychol. Learn. Motiv. Adv. Res. Theory. (Academic Press, San Diego, CA), 1-64.

Battilana J, Dorado S (2010) Building Sustainable Hybrid Organizations: The Case of Commercial Microfinance Organizations. Acad. Manage. J. 53(6):1419-1440.

Beckert J (2016) Imagined Futures (Harvard University Press, Cambridge, MA).

Benjamin B (2017) Asset \& Wealth Management Insights-Asset Management 2020: Taking Stock. PWC Lond. UK.

Boltanski L, Thévenot L (2006) On Justification: Economies of Worth (Princeton University Press, Princeton, $\mathrm{NJ})$.

Brovelli L, Drago X, Molinié E (2013) Responsibilité et performance des organisations: 20 Propositions pour renforcer la démarche de responsabilité sociale des entreprises (RSE) (Ministère de l'Economie et des Finances, Ministère du Commerce Exterieur, Ministère de l'Ecologie dy Développement Durable et de l'Energue, Ministère du Travail, de l'Emploi, de la Formation Professionelle et du Dialogue Social, Paris, France).

Charmaz K, Belgrave L (2002) Qualitative interviewing and grounded theory analysis. Gubrium JF, Holstein JA, Marvasti AB, McKinney KD, eds. SAGE Handb. Interview Res. Complex. Craft. (SAGE Publications, Thousand Oaks, CA), 347-367.

Chiles TH, Meyer AD, Hench TJ (2004) Organizational emergence: The origin and transformation of Branson, Missouri's musical theaters. Organ. Sci. 15(5):499-519.

Citigroup (2017) Citigroup's Declaration. Retrieved (February 7, 2018), https://www.bloomberg.com/news/articles/2017-11-02/as-credit-booms-citi-sayssynthetic-cdos-may-reach-100-billion.

Creed WED, Dejordy R, Lok J (2010) Being the change: Resolving institutional contradiction through identity work. Acad. Manage. J. 53(6):1336-1364.

Crifo P, Durand R, Gond JP (2018) Encouraging Investors to Enable Corporate Sustainability Transitions: The Case of Responsible Investment in France. Unpubl. Work. Pap.

Dacin MT, Dacin PA, Tracey P (2011) Social entrepreneurship: A critique and future directions. Organ. Sci. 22(5):1203-1213. 
Davis GF (2010) Not just a mortgage crisis: How finance maimed society. Strateg. Organ. 8(1):7582.

Davis GF, Marquis C (2005) Prospects for organization theory in the early twenty-first century: Institutional fields and mechanisms. Organ. Sci. 16(4):332-343.

De Bakker FG, Den Hond F, King B, Weber K (2013) Social movements, civil society and corporations: Taking stock and looking ahead. Organ. Stud. 34(5-6):573-593.

DiMaggio P (1987) Classification in art. Am. Sociol. Rev::440-455.

Durand R, Boulongne R (2017) Advancing research on categories for institutional approaches of organizations. Greenwood R, Oliver C, Lawrence T, Meyer RE, eds. SAGE Handb. Organ. Institutionalism. (London: UK), 647-668.

Durand R, Georgallis P (2018) Differential firm commitment to industries supported by social movement organizations. Organ. Sci. 29(1):154-171.

Durand R, Khaire M (2017) Where do market categories come from and how? Distinguishing category creation from category emergence. J. Manag. 43(1):87-110.

Durand R, Paolella L (2013) Category stretching: Reorienting research on categories in strategy, entrepreneurship, and organization theory. J. Manag. Stud. 50(6):1100-1123.

Durand R, Thornton P (2018) Categorizing Institutional Logics, Institutionalizing Categories: A Review of Two Literatures. Acad. Manag. Ann. 12(2):631-658.

Ernst \& Young (2011) Islamic Funds \& Investments Report 2011: Achieving Growth in Challenging Times (Ernst \& Young).

Espeland WN, Stevens ML (1998) Commensuration as a Social Process. Hagan J, Cook KS, eds. Annu. Rev. Sociol. (CA: Annual Reviews, Palo Alto, CA), 313-343.

European Fund and Asset Management Association (2015) Asset Management in Europe: Facts and Figures (European Fund and Asset Management Association (EFAMA), Brussels, Belgium).

Fourcade M, Healy K (2007) Moral views of market society. Annu. Rev. Sociol. 33:285-311.

Fourcade M, Steiner P, Streeck W, Woll C (2013) Moral categories in the financial crisis. SocioEcon. Rev. 11(3):601-627.

Garud R, Gehman J, Karnøe P (2010) Categorization by association: Nuclear technology and emission-free electricity. Res. Sociol. Work 21:51-93.

Giamporcaro S, Gond JP (2016) Calculability as politics in the construction of markets: The case of socially responsible investment in France. Organ. Stud. 37(4):465-495.

Glynn MA, Lounsbury M (2005) From the Critics' Corner: Logic Blending, Discursive Change and Authenticity in a Cultural Production System. J. Manag. Stud. 42(5):1031-1055.

Goldberg A, Hannan MT, Kovács B (2016) What does it mean to span cultural boundaries? Variety and atypicality in cultural consumption. Am. Sociol. Rev. 81(2):215-241.

Gond JP, Boxenbaum E (2013) The glocalization of responsible investment: Contextualization work in France and Quebec. J. Bus. Ethics 115(4):707-721.

Granqvist N, Grodal S, Woolley JL (2013) Hedging your bets: Explaining executives' market labeling strategies in nanotechnology. Organ. Sci. 24(2):395-413.

Granqvist N, Ritvala T (2015) Beyond prototypes: Drivers of market categorization in functional foods and nanotechnology. J. Manag. Stud. 53(2):210-237.

Greene J, Haidt J (2002) How (and where) does moral judgment work? Trends Cogn. Sci. 6(12):517-523.

Greene JD, Sommerville RB, Nystrom LE, Darley JM, Cohen JD (2001) An fMRI investigation of emotional engagement in moral judgment. Science 293(5537):2105-2108.

Hannan MT, Pólos L, Carroll GR (2007) Logics of Organization Theory: Audiences, Codes, and Ecologies (Princeton University Press, Princeton, NJ).

Hasan M, Dridi J (2011) The effects of the global crisis on Islamic and conventional banks: A comparative study. J. Int. Commer. Econ. Policy 2(02):163-200. 
Haveman HA, Rao H (1997) Structuring a theory of moral sentiments: Institutional and organizational coevolution in the early thrift industry. Am. J. Sociol. 102(6):1606-1651.

Hayat R, Den Butter F, Kock U (2013) Halal certification for financial products: A transaction cost perspective. J. Bus. Ethics 117(3):601-613.

Hiatt SR, Sine WD, Tolbert PS (2009) From Pabst to Pepsi: The deinstitutionalization of social practices and the creation of entrepreneurial opportunities. Adm. Sci. Q. 54(4):635-667.

Ho K (2009) Liquidated: An Ethnography of W all Street (Duke University Press, Durham, NC).

Hoffman AJ, Ocasio W (2001) Not all events are attended equally: Toward a middle-range theory of industry attention to external events. Organ. Sci. 12(4):414-434.

Hollande F (2012) Mon véritable adversaire, c'est le monde de la finance. (Discours du Bouget, 22 Janvier 2012, Bourget, France).

Hollensbe E, Wookey C, Hickey L, George G, Nichols CV (2014) Organizations with purpose. Acad. Manage. J. 57(5):1227-1234.

Hsu G (2006) Jacks of all trades and masters of none: Audiences' reactions to spanning genres in feature film production. Adm. Sci. Q. 51(3):420-450.

Hsu G, Grodal S (2015) Category taken-for-grantedness as a strategic opportunity The case of light cigarettes, 1964 to 1993. Am. Sociol. Rev. 80(1):28-62.

Hsu G, Hannan MT, Koçak Ö (2009) Multiple category memberships in markets: An integrative theory and two empirical tests. Am. Sociol. Rev. 74(1):150-169.

Huault I, Rainelli-Weiss H (2011) A market for weather risk? Conflicting metrics, attempts at compromise, and limits to commensuration. Organ. Stud. 32(10):1395-1419.

International Financing Review (2018) 2017 Review of the Year (Thomson Reuters, London, UK).

International Monetary Fund (2008) Global Financial Stability Report: Financial Stress and Deleveraging-Macro-financial Implications and Policy (International Monetary Fund, Washington, DC).

International Monetary Fund (2015) Global Financial Stability Report: Navigating Monetary Policy Challenges and Managing Risks (International Monetary Fund, Washington, DC).

Jackall R (1988) The World of Corporate Managers (Oxford University Press, New York).

Kant I (1790) The Critique of Judgment (Theory of the Aesthetic Judgment \& Theory of the Teleological Judgment) (e-artnow (ebook published in 2015)).

Karpik L (2010) Valuing the Unique: The Economics of Singularities (Princeton University Press Princeton).

Khaire M, Wadhwani DR (2010) Changing landscapes: The construction of meaning and value in a new market category - Modern Indian art. Acad. Manage. J. 53(6):1281-1304.

Knorr-Cetina K, Preda A eds. (2012) The Oxford Handbook of the Sociology of Finance (Oxford University Press, Oxford, UK).

Kodeih F, Bouchikhi H, Gauthier V (2018) Competing Through Categorization: Product-and Audience-Centric Strategies in an Evolving Categorical Structure. Organ. Stud::0170840618772597.

Label ISR (2016) Le label ISR en résumé-particuliers. Retrieved (December 5, 2016), http://www.lelabelisr.fr/le-label-isr-en-resume-particuliers.

Langley A (1999) Strategies for theorizing from process data. Acad. Manage. Rev. 24(4):691-710.

Lee BH, Hiatt SR, Lounsbury M (2017) Market mediators and the trade-offs of legitimacyseeking behaviors in a nascent category. Organ. Sci. 28(3):447-470.

Lok J (2010) Institutional logics as identity projects. Acad. Manage. J. 53(6):1305-1335.

Louche C, Lydenberg SD (2006) Investissement socialement responsable: Différences entre Europe et Etats-Unis. Rev. Econ. Financ. 85:81-105.

Lounsbury M (2001) Institutional source of practice variation: Staffing college and university recycling programs. Adm. Sci. Quartely 46:29-56. 
Lounsbury M, Rao H (2004) Sources of durability and change in market classifications: A study of the reconstitution of product categories in the American mutual fund industry, 19441985. Soc. Forces 82:969-999.

Lounsbury M, Ventresca MJ, Hirsch PM (2003) Social movements, field frames and industry emergence: A cultural-political perspective on US recycling. Socio-Econ. Rev. 1(1):71-104.

Louvel Y, Rivoalan S (2010) Investissement Socialement Responsable: l'heure du tri. Amis Terre.

Lund S, Daravula T, Dobbs R, Harle P, Kwek JH, Falcon R (2013) Financial globalization: Retreat or reset? (McKinsey Global Institute, New York).

MacKenzie D (2011) The credit crisis as a problem in the sociology of knowledge. Am. J. Sociol. 116(6):1778-1841.

MacKenzie D, Spears T (2014) "A device for being able to book P\&L”: The organizational embedding of the Gaussian Copula. Soc. Stud. Sci. 44(3):418-440.

Marti E, Scherer A (2016) Financial regulation and social welfare: The critical contribution of management theory. Acad. Manage. Rev. 41(2):298-323.

Massa FG, Helms WS, Voronov M, Wang L (2017) Emotions uncorked: Inspiring evangelism for the emerging practice of cool-climate winemaking in Ontario. Acad. Manage.J. 60(2):461-499.

Ministre des Finances et des Comptes Publics (2016) Cabier des charges du label ISR soutenu par les pouvoirs publics (Ministre des Finances et des Comptes Publics, Paris, France).

Moll J, de Oliveira-Souza R (2007) Moral judgments, emotions and the utilitarian brain. Trends Cogn. Sci. 11(8):319-321.

Murphy G (2002) The Big Book of Concepts (MIT Press, Boston, MA).

Negro G, Hannan MT, Rao H (2011) Category reinterpretation and defection: Modernism and tradition in Italian winemaking. Organ. Sci. 22(6):1449-1463.

Novethic (2015) 2014 Figures on Responsible Investment in France (Novethic, Paris, France).

Ortiz H (2014) Valeur financière et vérité: Enquête d'anthropologie politique sur l'évaluation des entreprises cotées en bourse (Les Presses de SciencesPo).

Ozcan P, Gurses K (2017) Playing cat and mouse: Contests over regulatory categorization of dietary supplements in the US. Acad. Manage. J. ePub ahead of print February 20, https://journals.aom.org/doi/abs/10.5465/amj.2015.1221.

Paolella L, Durand R (2016) Category spanning, evaluation, and performance: Revised theory and test on the corporate law market. Acad. Manage. J. 59(1):330-351.

Phillips DJ, Turco CJ, Zuckerman EW (2013) Betrayal as market barrier: Identity-based limits to diversification among high-status corporate law firms. Am. J. Sociol. 118(4):1023-1054.

Pitluck AZ (2012) Islamic banking and finance: Alternative or façade? Cetina KK, Preda A, eds. Oxf. Handb. Sociol. Finance. (Oxford University Press Oxford, Oxford, UK), 431-449.

Pontikes EG (2012) Two sides of the same coin: How ambiguous classification affects multiple audiences' evaluations. Adm. Sci. Q. 57(1):81-118.

Pontikes EG, Barnett WP (2015) The persistence of lenient market categories. Organ. Sci. 26(5):1415-1431.

Pozner JE, Stimmler MK, Hirsch PM (2010) Terminal isomorphism and the self-destructive potential of success: Lessons from subprime mortgage origination and securitization. Res. Sociol. Organ. 30(A):183-216.

Quattrone P (2015) Governing social orders, unfolding rationality, and Jesuit accounting practices: A procedural approach to institutional logics. Adm. Sci. Q. 60(3):411-445.

Rao H, Monin P, Durand R (2003) Institutional change in toque ville: Nouvelle cuisine as an identity movement in French gastronomy. Am. J. Sociol. 108(4):795-843.

Reinecke J, Ansari S (2015) What is a "fair" price? Ethics as sensemaking. Organ. Sci. 26(3):867888.

Russell SJ, Norvig P (2016) Artificial Intelligence: A Modern Approach (Malaysia; Pearson Education Limited). 
Sapin M (2014) Place de Paris 2020 - La finance au service de l'économie - Réunion du Comité du 1er décembre 2014 (Ministre des Finances et des Comptes Publics, Paris, France).

Sapin M (2015) Lancement du label "Investissement socialement responsable" soutenu par les pouvoirs publics, Déclaration du 28 Septembre 2015 (Ministre des Finances et des Comptes Publics, Paris, France).

Schneiberg M, Berk G (2010) From categorical imperative to learning by categories: Cost accounting and new categorical practices in American manufacturing, 1900-1930. Hsu G, Negro G, Koçak Ö, eds. Categ. Mark. Orig. Evol. Res. Sociol. Organ. Vol. 31. (Emerald Publishing Limited, Binlgey, UK), 255-292.

Smith A (1759) The theory of moral sentiments, ed. DD Raphael AL Macfie Lib. FundOriginal Work Publ. 1759ELK.

Strauss A, Corbin J (1998) Basics of Qualitative Research: Techniques and Procedures for Developing Grounded Theory Second. (Sage, Thousand Oaks, CA).

Suarez FF, Grodal S, Gotsopoulos A (2015) Perfect timing? Dominant category, dominant design, and the window of opportunity for firm entry. Strateg. Manag. J. 36(3):437-448.

Tew C, Barbieri C (2012) The perceived benefits of agritourism: The provider's perspective. Tour. Manag. 33(1):215-224.

TheCityUK (2014) Fund Management 2013.

Vergne JP, Swain G (2017) Categorical anarchy in the UK? The British media's classification of bitcoin and the limits of categorization. Durand R, Granqvist N, Tyllström A, eds. Categ. Categ. Stud. Sociol. Organ. Strategy Crossroads Res. Sociol. Organ. Vol. 51. (Emerald Publishing Limited, Bingley, UK), 185-222.

Vergne JP, Wry T (2014) Categorizing categorization research: Review, integration and future directions. J. Manag. Stud. 51(1):56-94.

Voronov M, De Clercq D, Hinings C (2013) Institutional complexity and logic engagement: An investigation of Ontario fine wine. Hum. Relat. 66(12):1563-1596.

Warde I (2000) Islamic Finance in the Global Economy (Edinburgh University Press, Edinburgh, UK).

Watkiss L (2013) New technology as equivoque: Time and experience in sensemaking and sensegiving about Apple's iPad. (Academy of Management Proceedings), 10342.

Weber K, Heinze KL, DeSoucey M (2008) Forage for thought: Mobilizing codes in the movement for grass-fed meat and dairy products. Adm. Sci. Q. 53(3):529-567.

Yan S, Ferraro F, Almandoz J (2018) The rise of socially responsible investment funds: The paradoxical role of the financial logic. Adm. Sci. Q.:0001839218773324.

Yin RK (2013) Case Study Research: Design and Methods (Sage Publications, Thousand Oakes, CA).

Zelizer VA (1978) Human values and the market: The case of life insurance and death in 19thcentury America. Am. J. Sociol. 84(3):591-610.

Zhai X, Gu J, Liu H, Liang JC, Chin-Chung T (2017) An experiential learning perspective on students' satisfaction model in a flipped classroom context. J. Educ. Technol. Soc. 20(1):198.

Zuckerman EW (2017) The categorical imperative revisited: Implications of categorization as a theoretical tool. Durand R, Granqvist N, Tyllström A, eds. Categ. Categ. Stud. Sociol. Organ. Strategy Crossroads Res. Sociol. Organ. Vol. 51. (Emerald Publishing Limited, Bingley, UK), $31-68$. 


\section{LIST OF FIGURES}

Figure 1. Evolution of French SRI Assets, 2003-2015 (€ billion) (Source: Novethic)

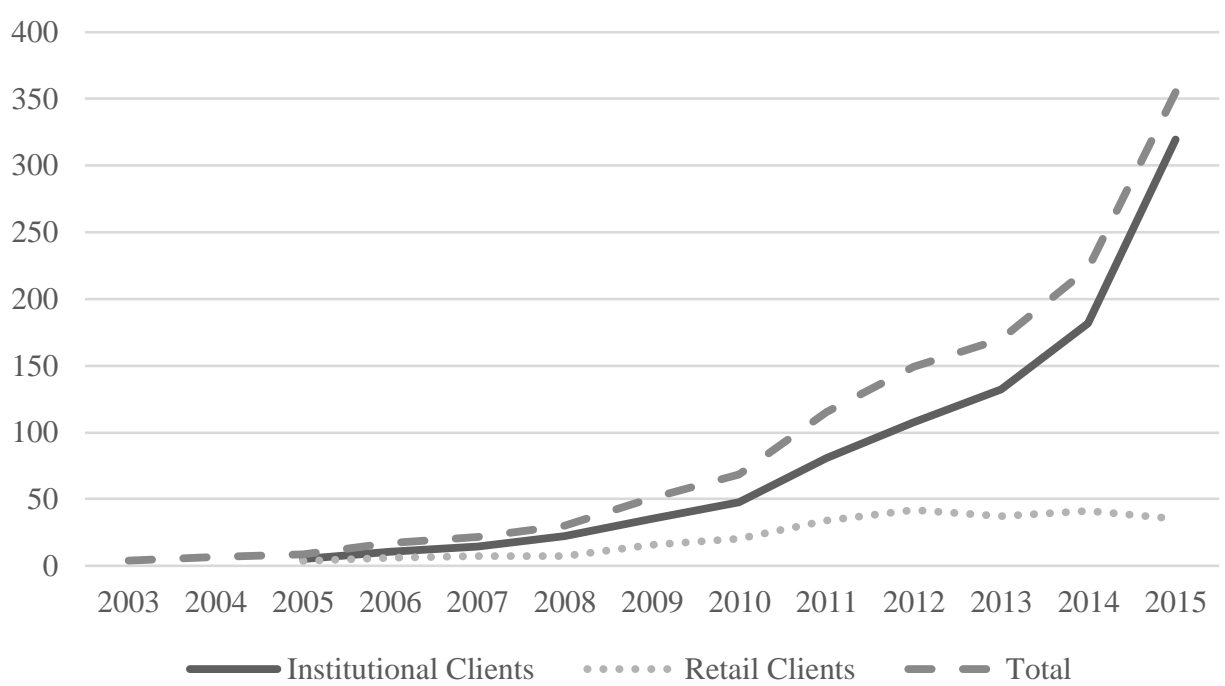

Note. SRI = Socially Responsible Investment; Novethic counts all funds that label themselves SRI; figures adjusted in 2015 due to a change in Novethic's methodology.

Figure 2. Data Structure

1st Order Codes

- Ideological dimension

- Contradictory goals

- Competing definitions

- Increased public scrutiny

- Difficulties of selling the product to clients

- Difficulties of straddling morals and markets

- The problem of standardization

- Different views on regulation

- Importance for retail investors of questioning themselves

- Need to demonstrate why SRI funds differ from conventional funds $2^{\text {nd }}$ Order Codes Aggregate Constructs

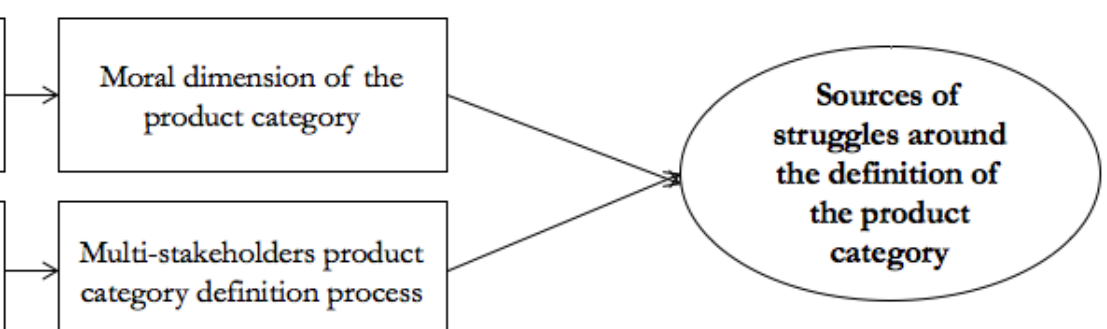

At the organizational level: organizational constraints and paradoxes

At the industry level: reconsidering the importance of labels

At the societal level: difficulties of legitimating the product category

Note. SRI = socially responsible investment. 
Figure 3. Timeline of Events in Defining the SRI Product Category, 1997-2015

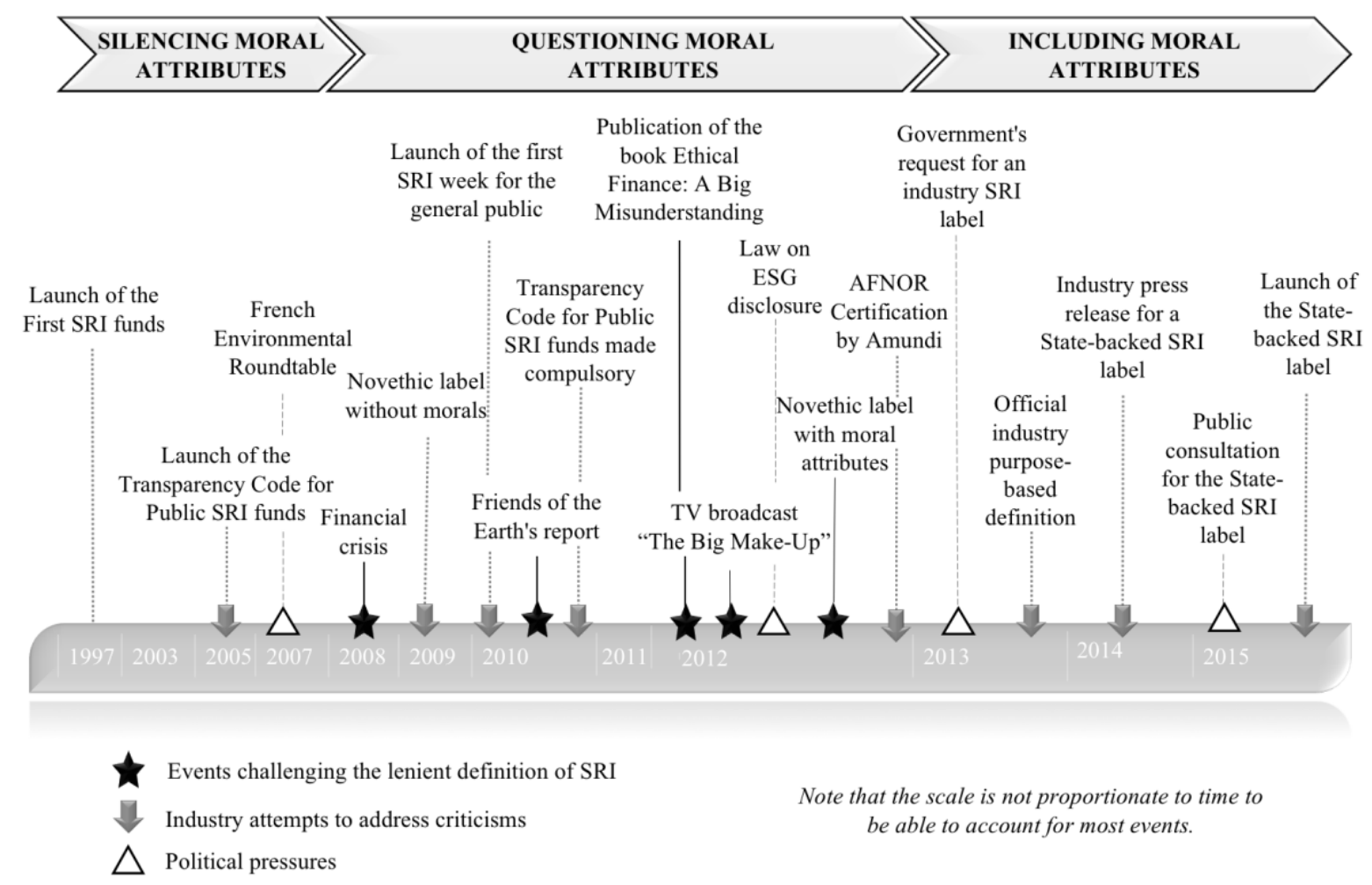

Notes. SRI $=$ socially responsible investment; ESG $=$ environmental, social, and governance; AFNOR = Association Française de Normalisation, or French Association of Normalization.

Figure 4. Percentage of Novethic SRI-labeled Mutual Funds, 2009-2014

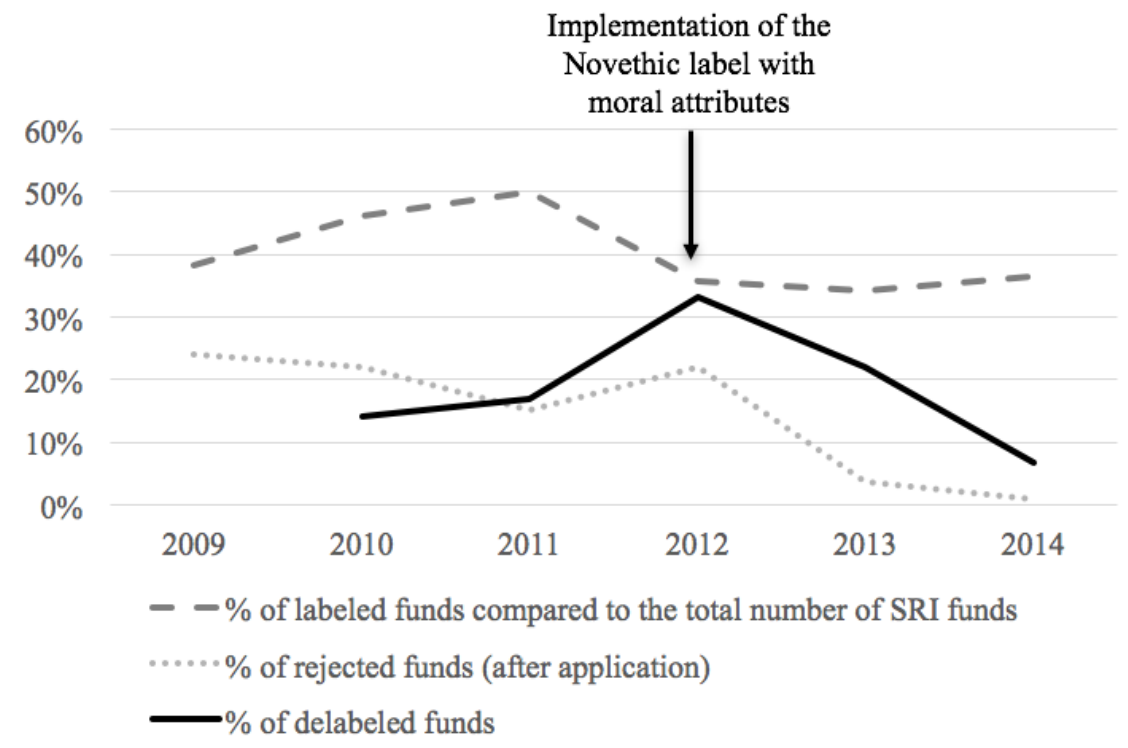

Note. SRI = socially responsible investment. In 2014, the number of SRI funds was estimated to be 409 out of a total of 2,875 funds managed by 67 asset management companies, meaning that SRI funds represented $14.2 \%$ of the total number of French mutual funds (source: AFG and AMF). 
Figure 5. Judgment Framework of the Product Category Definition

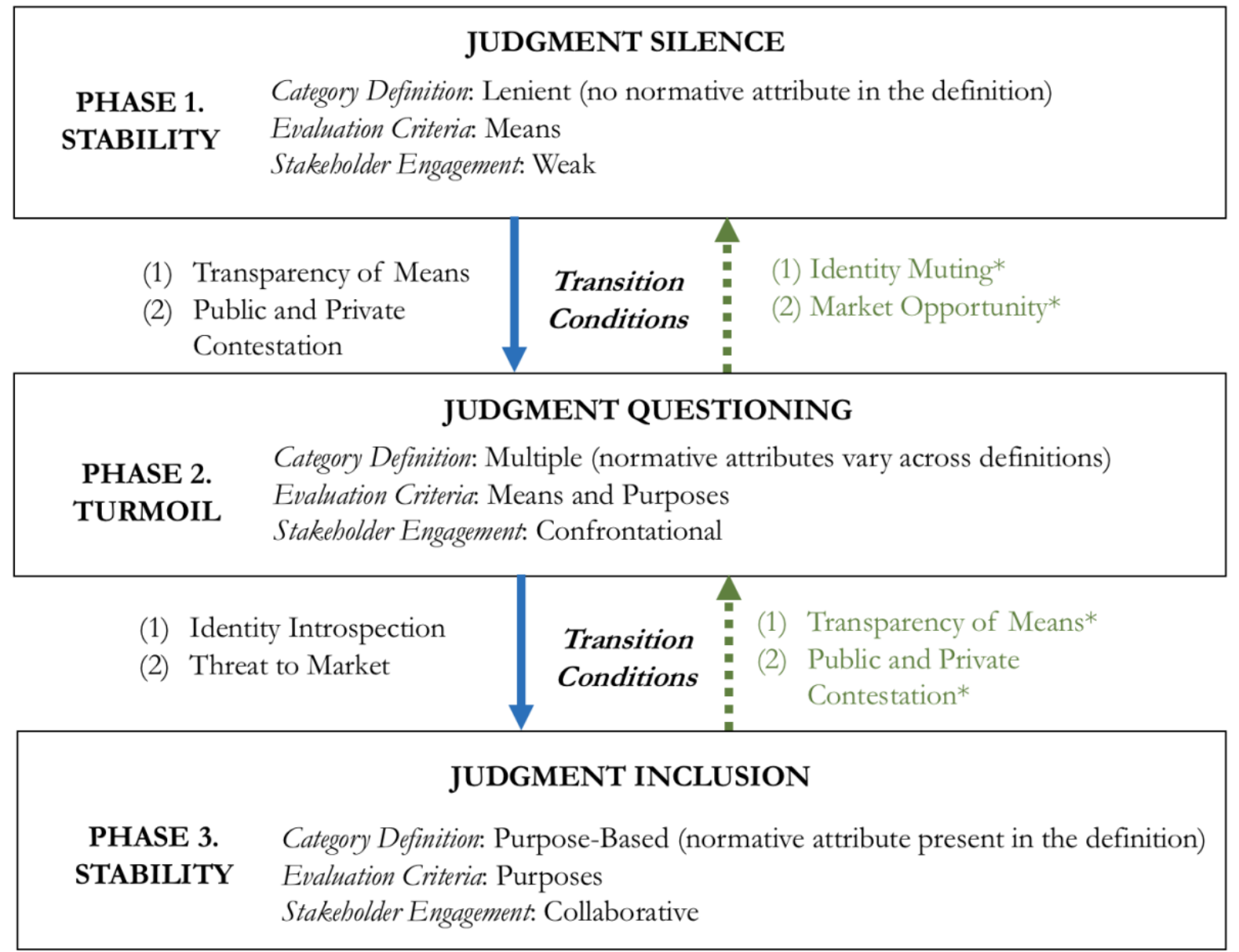

*Framework extension

Figure 6. Different Paths of Judgment Framing

Judgment Inclusion Judgment Silencing

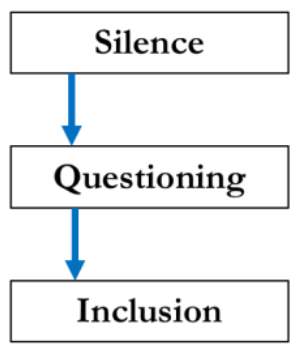

Example:

SRI

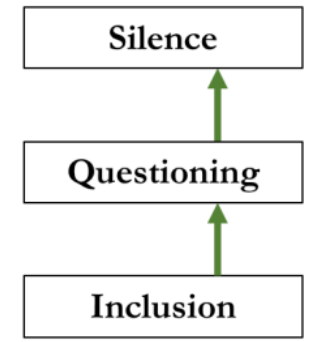

Example:

Islamic Finance*
Reversion to Silence

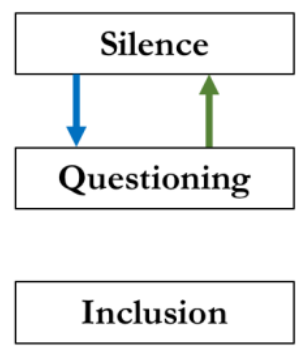

Example:

CDOs*
Judgment Maintenance

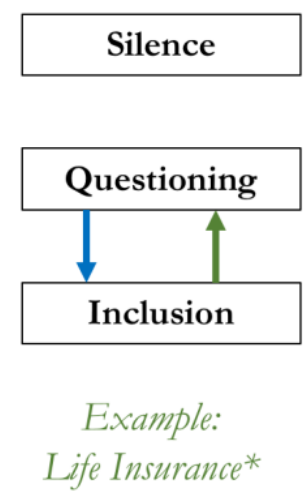

*Framework extension

Notes. SRI = socially responsible investment; $\mathrm{CDOs}=$ collaterized debt obligations. 
Appendix 1. Details of Interviews

\begin{tabular}{lllll}
\hline \multirow{3}{*}{ Organization } & & \multicolumn{3}{c}{ Number of Interviews } \\
\cline { 3 - 4 } & Function & $2006-$ & $2010-$ & $2015-$ \\
& & 2009 & 2014 & 2017
\end{tabular}

Asset Management Companies

Asset Management Company A

Asset Management Company B

Asset Management Company C

Asset Management Company D

Asset Management Company D

Asset Management Company D

Asset Management Company E

Asset Management Company F

Asset Management Company G Asset Management Company H Asset Management Company I Asset Management Company J Asset Management Company K Asset Management Company M Asset Management Company M Asset Management Company M Asset Management Company N Asset Management Company O Asset Management Company P

$\begin{array}{llll}\text { Head of SRI } & 1 & 0 & 0 \\ \text { Head of SRI } & 1 & 0 & 0 \\ \text { Head of SRI } & 1 & 0 & 0 \\ \text { SRI Analyst } & 1 & 0 & 1 \\ \text { CEO \& Head of SRI } & 1 & 0 & 0 \\ \text { Head of SRI } & 0 & 0 & 1 \\ \text { Head of European Fund } & 1 & 0 & 0 \\ \text { Distribution \& CEO France } & & & \\ \text { Head of SRI \& 2 SRI } & 0 & 1 & 0 \\ \text { Analysts } & & & \\ \text { Head of SRI } & 0 & 1 & 0 \\ \text { Head of SRI } & 0 & 1 & 0 \\ \text { Head of SRI } & 0 & 1 & 0 \\ \text { Head of SRI } & 0 & 1 & 0 \\ \text { Head of SRI } & 0 & 1 & 0 \\ \text { Head of SRI Research } & 0 & 1 & 0 \\ \text { Head of SRI } & 0 & 1 & 0 \\ \text { Head of SRI Promotion } & 0 & 1 & 3 \\ \text { Head of SRI } & 0 & 0 & 1 \\ \text { Head of Research } & 0 & 0 & 1 \\ \text { CEO \& Head of SRI } & 0 & 0 & 1\end{array}$

Public Authorities

\begin{tabular}{llcc}
\hline French Financial Authorities (AMF) & $\begin{array}{l}\text { Project Managers } \\
\text { responsible for writing the } \\
\text { AMF report on SRI (2) }\end{array}$ & 0 & 1 \\
Ministry of Ecology, Sustainable & $\begin{array}{l}\text { Project Officers, } \\
\text { Sustainable Finance (3) \& } \\
\text { Senelopment and Energy }\end{array}$ & 0 & 1 \\
Ministry for Finance and Economy & $\begin{array}{l}\text { Responsible Finance } \\
\text { Deputy Head of Savings } \\
\text { and Financial Markets }\end{array}$ & 0 & 0
\end{tabular}

Potential Users of SRI Labels

\begin{tabular}{|c|c|c|c|c|}
\hline Insurance Company A & $\begin{array}{l}\text { CSR Group \& Project } \\
\text { Manager }\end{array}$ & 1 & 0 & 0 \\
\hline Insurance Company A & $\begin{array}{l}\text { CSR France \& Project } \\
\text { Manager }\end{array}$ & 1 & 0 & 0 \\
\hline Insurance Company B & Head of Corporate CSR & 1 & 0 & 0 \\
\hline Insurance Company DB & Project Manager & 1 & 0 & 0 \\
\hline Bank A & Head of Corporate CSR & 1 & 0 & 0 \\
\hline Bank B & Project Manager & 1 & 0 & 0 \\
\hline Bank C & CSR Deputy Director & 0 & 1 & 0 \\
\hline Bank D & CSR Project Manager & 0 & 1 & 0 \\
\hline Bank E & $\begin{array}{l}\text { Director of Development } \\
\text { for Regional Banks }\end{array}$ & 0 & 1 & 0 \\
\hline Bank F & Financial Adviser & 0 & 0 & 1 \\
\hline Utility Company & $\begin{array}{l}\text { Employee Savings Funds } \\
\text { Manager }\end{array}$ & 0 & 1 & 0 \\
\hline Savings Retirement Fund B & Trustee & 0 & 1 & 0 \\
\hline Savings Retirement Fund C & $\begin{array}{l}\text { Head of Responsible } \\
\text { Investment }\end{array}$ & 0 & 1 & 0 \\
\hline
\end{tabular}




\begin{tabular}{|c|c|c|c|c|}
\hline \multirow[b]{2}{*}{ Organization } & \multirow[b]{2}{*}{ Function } & \multicolumn{3}{|c|}{ Number of Interviews } \\
\hline & & $\begin{array}{l}2006- \\
2009\end{array}$ & $\begin{array}{l}2010- \\
2014\end{array}$ & $\begin{array}{l}2015- \\
2017\end{array}$ \\
\hline Savings Retirement Fund D & Trustees & 0 & 1 & 0 \\
\hline Savings Retirement Fund A & Head of Equity and SRI & 1 & 1 & 0 \\
\hline Savings Retirement Fund A & Trustee & 0 & 1 & 0 \\
\hline Consulting Firm A & Senior Consultant & 1 & 0 & 0 \\
\hline Consulting Firm B & Partner & 1 & 0 & 0 \\
\hline Consulting Firm C & Senior Consultant & 1 & 0 & 0 \\
\hline Consulting Firm D & Consultant & 1 & 0 & 0 \\
\hline $\begin{array}{l}\text { Savings Retirement Fund Board } \\
\text { Members' Association }\end{array}$ & Trustee & 0 & 0 & 2 \\
\hline \multicolumn{5}{|l|}{ Rating Agencies } \\
\hline Broker A & Head of SRI Research & 1 & 0 & 0 \\
\hline Broker B & Head of SRI Research & 1 & 0 & 0 \\
\hline Broker B & $\begin{array}{l}\text { Head of SRI Research \& } \\
\text { SRI Analyst }\end{array}$ & 1 & 0 & 0 \\
\hline Social Rating Agency A & Head of Research & 1 & 1 & 0 \\
\hline Social Rating Agency B & Head of Research & 1 & 0 & 0 \\
\hline Social Rating Agency C & Head of Research & 1 & 0 & 0 \\
\hline Social Rating Agency D & Head of Research & 1 & 0 & 0 \\
\hline Social Rating Agency E & $\begin{array}{l}\text { Senior Client Relationship } \\
\text { Manager }\end{array}$ & 1 & 0 & 0 \\
\hline \multicolumn{5}{|l|}{ Certification Bodies } \\
\hline Novethic & $\begin{array}{l}\text { Responsible for the SRI } \\
\text { label }\end{array}$ & 0 & 2 & 1 \\
\hline Certification Body A & $\begin{array}{l}\text { Responsible for the SRI } \\
\text { label project (abandoned) }\end{array}$ & 0 & 1 & 0 \\
\hline AFNOR & $\begin{array}{l}\text { Senior Project Manager, } \\
\text { ISO } 26000 \text { (CSR } \\
\text { certification) }\end{array}$ & 0 & 0 & 1 \\
\hline AFNOR & $\begin{array}{l}\text { Senior Project Manager, } \\
\text { SRI Certification }\end{array}$ & 0 & 0 & 1 \\
\hline $\begin{array}{l}\text { CIES Trade Union A (certification } \\
\text { body for employee savings funds) }\end{array}$ & Members (3) & 1 & 1 & 0 \\
\hline CIES Trade Union B & Members (2) & 1 & 0 & 0 \\
\hline CIES Trade Unions & Members (3) & 0 & 1 & 0 \\
\hline Finansol (certification body for & Director & 0 & 0 & 1 \\
\hline
\end{tabular}

profit-sharing funds)

Industry Representatives

\begin{tabular}{|c|c|c|c|c|}
\hline FrenchSIF (French lobby for SRI) & $\begin{array}{l}\text { Vice-President and } \\
\text { Secretary General }\end{array}$ & 0 & 1 & 0 \\
\hline FrenchSIF & Secretary General & 1 & 1 & 2 \\
\hline Eurosif (European lobby for SRI) & Head of Research & 0 & 1 & 0 \\
\hline $\begin{array}{l}\text { AFG (French Professional } \\
\text { Association of Asset Management) }\end{array}$ & Head of Research & 1 & 0 & 0 \\
\hline $\mathrm{AFG}$ & Chief Executive Officer & 1 & 0 & 0 \\
\hline AFG & Head of SRI Research & 0 & 1 & 0 \\
\hline AFG & $\begin{array}{l}\text { Head of Research \& SRI } \\
\text { Project Manager }\end{array}$ & 0 & 2 & 0 \\
\hline AFG & Responsible for SRI (2) & 0 & 1 & 1 \\
\hline \multicolumn{5}{|l|}{ Representatives of Civil Society } \\
\hline NGO A specialized in SRI & Head of SRI Research & 1 & 0 & 0 \\
\hline NGO B specialized in Finance & Project Manager & 1 & 0 & 0 \\
\hline Friends of the Earth & Responsible for SRI & 0 & 1 & 1 \\
\hline Movie \& Debate "I, Finance and & Movie Director & 0 & 1 & 0 \\
\hline
\end{tabular}

Sustainable Development" 


\begin{tabular}{llllc}
\hline \multirow{2}{*}{ Organization } & & \multicolumn{2}{c}{ Number of Interviews } \\
\cline { 3 - 5 } & Function & $\mathbf{2 0 0 6 -}$ & $\mathbf{2 0 1 0 -}$ & $\mathbf{2 0 1 5}-$ \\
& & $\mathbf{2 0 0 9}$ & $\mathbf{2 0 1 4}$ & $\mathbf{2 0 1 7}$ \\
\hline Alternative Finance Network & Director & 0 & 1 & 0 \\
Finance Watch & Head of Communications & 0 & 1 & 1 \\
Finance Watch & Secretary General & 0 & 1 & 0 \\
Think Tank A specialized in SRI & Project Manager & 1 & 0 & 1 \\
NGO C specialized in Finance & France Campaigner & 0 & 0 & 1 \\
NGO D specialized in Environment & President & 0 & 0 & 1 \\
NGO E specialized in Environment & Scientific Director & 0 & 0 & 1 \\
& & & & $\mathbf{2 7}$ \\
\hline TOTAL & & $\mathbf{3 3}$ & $\mathbf{3 6}$ & \\
\hline
\end{tabular}

Note. SRI = socially responsible investment; AMF = Autorité des marchés financiers, or financial markets regulator; ESG = environmental, social, and governance; CSR = corporate social responsibility; AFNOR = Association Française de Normalisation, or French Association of Normalization; CIES = Comité Intersyndical de l'Epargne Salariale or inter trade unions committee for employee saving funds; FrenchSIF $=$ French Sustainable Investment Forum, or Forum pour l'Investissement Responsable (FIR); AFG = Association Française de la Gestion Financière, or French professional association of asset management; NGO $=$ non-governmental organization. The types of stakeholders interviewed varied over the years, due to the changes in the definition process. For instance, rating agencies were initially expected to play a key role in the definition of SRI but later appeared to be not involved in the discussion. Likewise, the envisioned potential users of the SRI label evolved over time. 
Appendix 2. Expected Features of the French Public SRI Mutual Funds According to Each Organization (Source: Institutional Documents)

\begin{tabular}{|c|c|c|c|c|}
\hline $\begin{array}{l}\text { AFG-FrenchSIF } \\
\text { Transparency Code } \\
\text { (Industry Representatives) }\end{array}$ & $\begin{array}{l}\text { Novethic SRI Label } \\
\text { (with moral attributes) }\end{array}$ & $\begin{array}{l}\text { AFNOR } \\
\text { (National } \\
\text { Certification Body) }\end{array}$ & French State-Backed SRI Label & $\begin{array}{l}\text { AMF Report on SRI } \\
\text { (French Financial Authorities) }\end{array}$ \\
\hline 2005 & 2012 & 2013 & September 2015 & November 2015 \\
\hline $\begin{array}{l}\text { I-General information } \\
\text { The signatories must } \\
\text { disclose precise } \\
\text { information about the state } \\
\text { of the company and the } \\
\text { funds. } \\
\text { II - ESG information } \\
\text { criteria } \\
\text { The signatories must be } \\
\text { clear on the goal pursued } \\
\text { by the fund and its ESG } \\
\text { investment criteria. } \\
\text { III - ESG analysis process } \\
\text { The signatories commit to } \\
\text { disclosing clear } \\
\text { information on the ESG } \\
\text { analysis process for their } \\
\text { investments. } \\
\text { IV - Evaluation, selection } \\
\text { and investment policy } \\
\text { The signatories commit to } \\
\text { disclosing information on } \\
\text { how the ESG analysis is } \\
\text { used to construct and } \\
\text { manage their portfolios. } \\
\text { IV - Engagement policy } \\
\text { The signatories must } \\
\text { explain their engagement } \\
\text { policy if the fund has one. } \\
\text { V - Voting policy } \\
\text { The signatories commit to } \\
\text { being clear regarding their } \\
\text { voting policy. }\end{array}$ & $\begin{array}{l}\text { I- Integration of ESG analysis } \\
\text { - At least } 90 \% \text { of issuers must be } \\
\text { evaluated on the three dimensions } \\
\text { of ESG. } \\
\text { - The SRI exclusion rate of issuers } \\
\text { should be at least } 15 \% \text {. } \\
\text { - The global ESG quality of the } \\
\text { portfolio must be comparable to } \\
\text { other SRI funds. } \\
\text { II - Transparency of the process } \\
\text { - The asset manager must comply } \\
\text { with the Transparency Code } \\
\text { - The answer to the transparency } \\
\text { code should include updated } \\
\text { information on the means and the } \\
\text { selection steps of ESG values. } \\
\text { - The investment policy must } \\
\text { explicitly mention the exclusion of } \\
\text { manufacturers of weapons such as } \\
\text { mines and cluster bombs. } \\
\text { III - Non-financial reporting } \\
\text { - ESG reports should include } \\
\text { quantitative data on the ESG } \\
\text { features of the fund and the } \\
\text { exclusion rate of the SRI process, } \\
\text { and be published at least quarterly. } \\
\text { IV - Publication of the portfolio } \\
\text { - The portfolio must be published at } \\
\text { least once every } 6 \text { months and } \\
\text { must show the real issuers (not the } \\
\text { parent company or another } \\
\text { analyzed entity); the names of } \\
\text { issuers must be easily identifiable. }\end{array}$ & $\begin{array}{l}\text { The company } \\
\text { commits itself to: } \\
\text { - Analyzing the } \\
\text { defined ESG } \\
\text { criteria with } \\
\text { competence and } \\
\text { impartiality; } \\
\text { - Updating and } \\
\text { ensuring the } \\
\text { accuracy of the } \\
\text { ratings on a } \\
\text { regular basis; } \\
\text { - Constructing } \\
\text { portfolios by } \\
\text { respecting the } \\
\text { rigorous SRI } \\
\text { rules; } \\
\text { - Permanently } \\
\text { and independently } \\
\text { controlling } \\
\text { respect for the } \\
\text { SRI management } \\
\text { rules; } \\
\text { - Dialoguing and } \\
\text { voting in favor of } \\
\text { a progress-making } \\
\text { approach; } \\
\text { - Informing } \\
\text { clients with full } \\
\text { transparency; and } \\
\text { - Continuously } \\
\text { improving } \\
\text { practices. }\end{array}$ & $\begin{array}{l}\text { I-Goals pursued by the fund through the implementation of } \\
\text { ESG criteria for the issuers } \\
\text { General, financial and ESG-specific goals that are pursued by } \\
\text { integrating ESG criteria into the investment policy are clearly } \\
\text { defined in the commercial documents created for investors. } \\
\text { II - Methodology of analysis and rating of issuers implemented } \\
\text { by the asset management company } \\
\text { i) The ESG evaluation method is clearly described and the asset } \\
\text { management company of the fund demonstrates its ability to } \\
\text { take these criteria into account in its investment policy. } \\
\text { ii) The asset management company of the fund implements } \\
\text { internal or external reliable means to make its analysis and } \\
\text { demonstrates a real effort to analyze and comprehend the } \\
\text { information at its disposal (for at least } 90 \% \text { of issuers). } \\
\text { III - Implementation of ESG criteria into the construction and } \\
\text { life of the portfolio } \\
\text { i) The ESG strategy is explicitly defined and the result of the } \\
\text { implementation of this strategy is measured. } \\
\text { ii) The management of the fund follows a long-term strategy; the } \\
\text { use of derivative products is compatible with the goals of the } \\
\text { fund and congruent with its long-term perspective. } \\
\text { IV - ESG engagement policy (dialogue and voting) with issuers } \\
\text { The general voting policy and the implementation means are } \\
\text { congruent with the goals of the fund. } \\
\text { V - Reinforced transparency } \\
\text { i) Formal communication with distributors and investors is } \\
\text { implemented to guarantee that they understand the strategy and } \\
\text { the goals of the fund. } \\
\text { ii) Respect for SRI management rules is internally controlled and } \\
\text { clearly explained to investors. } \\
\text { VI - The demonstration of positive impacts on the development } \\
\text { of a sustainable economy } \\
\text { - ESG impact on the selected issuers is monitored. }\end{array}$ & $\begin{array}{l}\text { - Asset management companies should } \\
\text { maintain cohesiveness between the } \\
\text { different available sources of } \\
\text { information, particularly across } \\
\text { commercial and legal documents and in } \\
\text { the Transparency Code. } \\
\text { Legal and commercial documents } \\
\text { associated with SRI mutual funds should } \\
\text { include: } \\
\text { - a managerial goal with non-financial } \\
\text { dimensions; } \\
\text { - the type(s) of SRI adopted; and } \\
\text { - elements regarding the selection and } \\
\text { management methods used. } \\
\text { - Any fund that is commercialized in } \\
\text { France and wants to emphasize its SRI } \\
\text { characteristic should publish a document } \\
\text { that explains its approach, which follows } \\
\text { the model of the Transparency Code, or } \\
\text { adopt a charter, code, or label that relates } \\
\text { to the integration of criteria that deal } \\
\text { with ESG goals. } \\
\text { - If the asset management company } \\
\text { adopts a shareholder engagement policy, } \\
\text { it should indicate where to find the } \\
\text { documents that enable a better } \\
\text { understanding of these dimensions } \\
\text { (proxy voting and dialogue). } \\
\text { - Non-financial reports (integrated or } \\
\text { not into standard financial reports) } \\
\text { should be easily accessible on the } \\
\text { Internet pages dedicated to SRI funds } \\
\text { and updated at least annually. }\end{array}$ \\
\hline
\end{tabular}

Notes. SRI = socially responsible investment; AFG = Association Française de la Gestion Financière, or French professional association of asset management; FrenchSIF = French Sustainable

Investment Forum, or Forum pour l'Investissement Responsable (FIR); AFNOR = Association Française de Normalisation, or French Association of Normalization; AMF = Autorité des marchés financiers, or financial markets regulator, ESG = environmental, social, and governance. 